\title{
A Roadmap for the Synthesis of Separation Networks for the Recovery of Bio- based Chemicals: Matching Biological and Process Feasibility
}

\author{
Kirti M. Yenkie, WenZhao Wu, Ryan L. Clark, Brian F. Pfleger, Thatcher W. Root, Christos T. \\ Maravelias*
}

Department of Chemical and Biological Engineering, University of Wisconsin-Madison, Madison, WI 53706

\author{
* Correspondence: Christos T. Maravelias
}

Email: maravelias@wisc.edu, Tel: 1-608-265-9026, Fax (608) 262-5434

Address: University of Wisconsin - Madison, Department of Chemical and Biological Engineering, 1415 Engineering Drive, Madison, Wisconsin 53706-1691.

\begin{abstract}
Microbial conversion of renewable feedstocks to high-value chemicals is an attractive alternative to current petrochemical processes because it offers the potential to reduce net $\mathrm{CO}_{2}$ emissions and integrate with bioremediation objectives. Microbes have been genetically engineered to produce a growing number of high-value chemicals in sufficient titer, rate, and yield from renewable feedstocks. However, high-yield bioconversion is only one aspect of an economically viable process. Separation of biologically synthesized chemicals from process streams is a major challenge that can contribute to more than $70 \%$ of the total production costs. Thus, process feasibility is dependent upon the efficient selection of separation technologies. This selection is dependent on upstream processing or biological parameters, such as microbial species, product titer and yield, and localization. Our goal is to present a roadmap for selection of appropriate technologies and generation of separation schemes for efficient recovery of bio-based chemicals by utilizing information from upstream processing, separation science and commercial requirements. To achieve this, we use a separation system comprising of three stages: (I) cell and product isolation, (II) product concentration, and (III) product purification and refinement. In each stage, we review the technology alternatives available for different tasks in terms of separation principles, important operating conditions, performance parameters, advantages and disadvantages. We generate separation schemes based on product localization and its solubility in water, the two most distinguishing properties. Subsequently, we present ideas for simplification of these schemes based on additional properties, such as physical state, density, volatility, and intended use. This simplification selectively narrows down the technology options and can be used for systematic process synthesis and optimal recovery of bio-based chemicals.
\end{abstract}


Keywords: microbial cultivation, stage-wise separation, technology selection, physical property, product localization, solubility, process synthesis

\section{Introduction}

Over the last decade, the search for alternative, sustainable sources of energy, fuels and chemicals has been motivated by concern over climate change, energy security, and petroleum costs. Recent changes have reduced the latter concerns but long range projections suggest that they are likely to return. The International Energy Outlook, 2016 (Conti et al., 2016) predicts a 48\% increase in worldwide energy demand in the 28 year period from 2012 to 2040. Also, ongoing negotiations regarding climate change and energy economy (OECD, 2009; Sanders et al., 2007), have identified significant gaps between the 'current trends' of GHG emissions and energy consumption as compared to the 'expected trends' in order to control global warming (Moss et al., 2010; Peters et al., 2013) and sustain energy resources (Chang et al., 2014; Doshi et al., 2014) for the future. Latest advances in energy harnessing technologies from solar, wind, and geothermal power suggest that they have the potential to satisfy the increase in energy demand, but these strategies do not provide alternative sources for chemicals for industry (Marquardt et al., 2010). A significant amount of work has been done in the field of bioenergy and biofuel production from different sources of biomass including sugar crops, lignocellulosic biomass, and microalgae. However, a return to low petroleum prices has severely impacted the development of the biofuel sector. Consequently, researchers have turned their attention to the production of higher-value, bio-based chemicals (Philp, 2015) that can act as direct substitutes (i.e. the exact same petrochemical from biological route) or indirect alternatives (i.e. bio-based chemicals having similar functionality as petrochemicals, without duplicating the exact molecular structure)(Lipinsky, 1981). The economies of scale and the cost reductions created by operating a highly optimized (from numerous years of operation) petrochemical process make it very difficult for new bio-based processes to compete as direct substitutes (Cherubini and Strømman, 2011; Leeper and Andrews, 1991; Siddiqui et al., 2013). For these reasons, commercial success, (e.g. DuPont Sorona (Kurian, 2005)) has been limited to chemical products wherein the biological synthesis route is superior to existing petrochemical routes in terms of titer, rate, and yield.

In addition to carbon neutrality and bioremediation, production of chemicals from biological routes has other advantages. They have a higher selling price as compared to biofuels in terms of energy basis (Banholzer and Jones, 2013). The similar chemical composition of biomass to many functionalized commodity chemicals enables simplification of their production (Scott et al., 2007). For the ease of producing biofuels or bio-based chemicals the effective hydrogen to carbon ratio $\left(H / C_{\text {eff }}\right)$ as shown in Eq. (1) (Zhang et al., 2011) of the starting materials or feedstocks should be similar to the final products (Vennestrøm et al., 2011). The expression includes oxygen in the numerator to account for the overall 
degree of oxidation of a molecule. Comparing this ratio for the starting and the final material indicates the amount of deoxygenation required to achieve the desired product.

$$
H / C_{\mathrm{eff}}=\frac{n(H)-2 n(O)}{n(C)}
$$

The $H / C_{\text {eff }}$ ratio of transportation fuels is in the range of 1 to 2.3 , which is closer to the ratio found in crude oil; whereas, the $H / C_{\text {eff }}$ ratios for chemicals such as lactic acid (0), polyhydroxyalkanoates (0.5) and 2, 3-butanediol (1.5) tend to be much lower, which renders crude oil a poorer choice as a raw material for chemicals. However, substrates for microbial cultivation such as sugars ( $\sim 0)$, have an effective $H / C_{\text {eff }}$ ratio which is closer to many functionalized commodity chemicals, thus making them a better feedstock than crude oil or fossil resources. This proves to be a substantial argument in support of producing biobased chemicals in comparison to biofuels.

There are several methods for conversion of biomass to chemicals (Siddiqui et al., 2013) and these include thermochemical conversions (Huber et al., 2006; Chew and Doshi, 2011), catalytic conversions (Alonso et al., 2012; Chheda et al., 2007; Huber et al., 2005) and biological conversions through microbial cultivations (Brennan and Owende, 2010; Liao et al., 2016; Lynd et al., 2002). The operating conditions and parameters in upstream processing and technologies in downstream processing vary significantly for different biomass processing methods (Lipinsky, 1981). Thermochemical conversions such as biomass upgrading by torrefaction (van der Stelt et al., 2011) followed by gasification (Prins et al., 2006; Worley et al., 2012) require high temperatures $\left(>700^{\circ} \mathrm{C}\right)$ at which the potential advantage of biomass composition and structure is lost. Pyrolysis or thermal decomposition followed by catalytic upgrading involves multiple upgrading reactions and phase changes to produce biofuels and chemicals (Chheda et al., 2007; Dutta et al., 2015; Pham et al., 2014). On the other hand, microbial cultivations involve bioconversions of substrates (inorganic and organic) into desired chemicals through reactions that happen inside the micro-organisms and these can be modified and controlled through metabolic pathway engineering and synthetic biology (Angermayr et al., 2015; Jullesson et al., 2015; Tee et al., 2014). The variations in process conditions, product concentration and physical states of the components involved in these conversion methods require significantly different separation technologies for product recovery. In this paper, we study the separation technologies applicable to bio-based chemicals produced by microbial bioconversion.

The foremost concerns of large scale production of bio-based chemicals from microbial sources are the large volumes of water required to perform bioprocesses and the low biomass and product concentrations in the streams entering the separation network. Many regions in the world face the problem of water scarcity (Flörke et al., 2013; Schewe et al., 2014) and water is often mispriced while evaluating its usage in domestic and industrial sectors. Microbial cultivations may be water-intensive, but some microbial strains can be engineered to grow in wastewater and developments in recycling techniques can prove 
advantageous in implementing large-scale production in certain regions, thus making biological processes sustainable (Palsson et al., 1981).

The downstream processing costs to recover products from these dilute streams have been analyzed in the literature, especially for biofuels from microalgae (Davis et al., 2011; Rizwan et al., 2013), and most studies indicate that more than $70 \%$ of the overall production costs are incurred during separations (Brandt and Schembecker, 2016; Kiss et al., 2015; Shaeiwitz et al., 2000; Sikdar et al., 1989). Thus, we can say that downstream processing determines the overall process feasibility and poses the biggest challenge in commercialization of bio-based chemicals. These 'downstream processing' costs are heavily influenced by the characteristics of process streams coming from 'upstream processing'. Also, in upstream processing one might be tempted to select a micro-organism that enables faster strain modifications and simpler cultivation conditions. However, in doing so we might end up spending more on downstream separations and the overall process would be suboptimal (Davidson and Lievense, 2016). Thus, upstream (biological feasibility) and downstream (process feasibility) processing are interdependent.

The objective of this work is to devise a set of guidelines for development of separation processes for bio-based chemicals by utilizing information from upstream processing as well as specific product properties and final market requirements. In section 2, we briefly describe the critical parameters of 'upstream processing' used for determining the characteristics of process stream entering 'downstream processing'. Then in section 3 we discuss some features of downstream processing and propose its division into three stages. We present a comprehensive review of the separation technologies in stages I, II, and III in sections 4, 5, and 6 respectively. In section 7, we use product localization and its solubility in water to generate separation schemes which comprise of all possible technology options in each stage relevant to that product category. Subsequently, we demonstrate the simplification of these schemes based on additional product properties such as, physical state, density, volatility, and intended use by using an example. This simplification provides a reduced list of relevant technology alternatives for the specific product class. In section 8 , we discuss a roadmap for the selection of separation technologies for efficient recovery of bio-based chemicals.

\section{Upstream processing}

Upstream processing involves harvesting and conversion of carbon feedstocks into bioavailable substrates and subsequent upgrading to chemicals of interest. This section will discuss key factors affecting the process stream entering downstream processing, hereby addressed as 'process stream'. We consider the two most studied microbial processing routes utilizing substrates derived from atmospheric $\mathrm{CO}_{2}$ :

- Indirect $\mathrm{CO}_{2}$ utilization by heterotrophs - atmospheric $\mathrm{CO}_{2}$ is captured in terrestrial plant biomass, which is subsequently harvested, deconstructed into sugar-rich feedstocks, and converted to central metabolites by heterotrophic microorganisms (includes microalgae, bacteria, yeasts and fungi). 
- $\quad$ Direct $\mathrm{CO}_{2}$ utilization by photoautotrophs - $\mathrm{CO}_{2}$ from industrial process waste is captured and fixed to central metabolites by photoautotrophic microorganisms (includes microalgae and cyanobacteria).

In examining these routes, the primary focus will be on process stream characterization determined by factors, such as feedstocks and microbial cultivation methods. An overview of these factors and highlighted considerations are given in Figure 1.

\subsection{Indirect $\mathrm{CO}_{2}$ utilization by heterotrophs}

Accessible storage carbohydrates, such as corn starch or sugar cane juice, are historically the most commonly used sources of sugar for microbial fermentation due to their ease of saccharification (Bothast and Schlicher, 2005; Canilha et al., 2012). Lignin and structural carbohydrates including cellulose and hemicellulose are more recalcitrant, but are abundant in agricultural byproducts, such as corn stover or sugarcane bagasse. Structural carbohydrates are also the primary component of many potential energy crops, such as switchgrass, that do not compete with food crops, and woody biomass waste products from forest management. In order to convert these substrates into soluble sugars, a number of strategies both biological (Liao et al., 2016; Lynd et al., 2002) and physicochemical (Huber et al., 2006), are being investigated and have been reviewed by others.

Technoeconomic analyses have been performed for the conversion of plant-based carbohydrates into fermentable sugars, primarily for production of ethanol (Gnansounou and Dauriat, 2010; Hamelinck et al., 2005; Humbird et al., 2011) and other liquid biofuels (Han et al., 2015). In utilizing fermentable sugars for the production of bio-based chemicals it is important to consider the effects of their composition on microbial cultivation wherein a microorganism converts the sugars into central metabolites for growth and production of chemicals of interest through metabolically engineered pathways. Depending on the composition of the initial biomass as well as processing conditions, the process stream will contain some combination of fermentable sugars (primarily hexoses and pentoses) and potential fermentation inhibitors (phenolic compounds, terpenoids, organic acids, and reduced sugar products) whose concentration will affect the titer, productivity and yield of the microbial cultivation. Many of these molecules can also be carried over into the process stream as co-products (Hahn-Hagerdal et al., 2001).

\subsection{Direct $\mathrm{CO}_{2}$ utilization by photoautotrophs}

Photoautotrophic microorganisms, including cyanobacteria and microalgae, use photosynthetic pigments to capture photons from sunlight. The captured light energy is used to split water, reduce electron carriers, and produce a proton gradient (Lea-Smith et al., 2015). The process ultimately leads to generation of NADPH and ATP that is used to assimilate $\mathrm{CO}_{2}$ in the form of central metabolites through the Calvin-Benson-Bassham cycle (Nelson and Cox, 2008). These metabolites can then be upgraded to chemicals of interest through metabolic pathways analogous to those found in heterotrophic organisms. 
As the two major substrates for photoautotrophic process are $\mathrm{CO}_{2}$ and light, the considerations are very different from heterotrophic conversion of sugar. While photoautotrophic microorganisms can grow in ambient air, high-concentration $\mathrm{CO}_{2}$ streams can help deliver $\mathrm{CO}_{2}$ to the bioreactors at a rate necessary for large scale cultivations (Clark et al., 2014). These high-concentration streams can be generated by capturing $\mathrm{CO}_{2}$ from industrial emissions through emerging technologies (reviewed by (Mondal et al., 2012; Yang et al., 2008)) and transported to the site of photoautotrophic cultivation. Capture of industrial $\mathrm{CO}_{2}$ emissions is predicted to reduce the impact of GHG on the environment (Quintana et al., 2011) and will contribute to generating carbon-neutral chemical life cycles. Efficient light delivery is equally essential for enhanced productivity and $\mathrm{CO}_{2}$ fixation by photoautotrophs and will ultimately limit the final biomass titers of photoautotrophic cultures to values much lower than heterotrophic cultures. Many bioreactor designs have been considered for their ability to deliver light to photoautotrophic cultures, including open ponds and closed photobioreactors (Hulatt and Thomas, 2011; Jorquera et al., 2010; Sharma et al., 2013). The most important characteristic for determining titer, productivity and yield is the ratio of illuminated surface area to volume (Lee et al., 2014).

Due to the utilization of light as a substrate and the limitation of low biomass titer, photoautotrophic cultivations resemble a combination of agricultural and microbial processes and their areal and volumetric scales are much larger than those of heterotrophs. Thus, many factors have a larger effect on process costs and process stream characteristics, including capital costs, land use, water use, and nutrient sources. An open pond cultivation scheme could alleviate the cost-prohibitive capital investment associated with complex photobioreactors (Jones and Banholzer, 2014). The utilization of non-arable land addresses another important issue of food vs. fuel (Rosgaard et al., 2012). Many species can grow in salt water and utilize nutrients from wastewater, reducing fresh water usage.

\subsection{Process stream characteristics}

Once atmospheric carbon has been converted to central metabolites through the routes described in subsections 2.1 and 2.2, a vast number of metabolic pathways can be used to upgrade these molecules into chemicals of interest. Enhancement of yield and productivity of target molecules is possible through metabolic engineering of these pathways (Angermayr et al., 2015; Knoop and Steuer, 2015) and can vary greatly based on the host organism (Jullesson et al., 2015; Liao et al., 2016). Modern biocatalyst development integrates multiple operations from classical metabolic engineering, systems biology, evolution, reverse engineering and synthetic biology (Tee et al., 2014) to enhance critical host metrics such as titer, rate (productivity), and yield (a.k.a. TRY). Some examples of these metrics are shown in Table 1 for heterotrophic cultivations and in Table 2 for photoautotrophic cultivations. 
Table 1 Sample metrics for heterotrophic microbial processing route with details about product localization, microbial species, typical biomass titers, productivity, yields and potential co-products.

\begin{tabular}{|c|c|c|c|c|c|c|c|}
\hline \multicolumn{2}{|c|}{ Energy Source } & \multicolumn{2}{|c|}{ Carbon Source } & \multicolumn{2}{|c|}{ Biomass Titer } & \multicolumn{2}{|c|}{ Biomass Productivity } \\
\hline \multicolumn{2}{|c|}{ Organic Carbon } & \multicolumn{2}{|c|}{ Organic Carbon } & \multicolumn{2}{|c|}{$\begin{array}{l}\text { High } \\
(100-268 \mathrm{~g} / \mathrm{L})\end{array}$} & \multicolumn{2}{|c|}{$\begin{array}{l}\text { High } \\
(0.01-6.6 \mathrm{~g} / \mathrm{L}-\mathrm{h})\end{array}$} \\
\hline $\begin{array}{l}\text { Localization } \\
\text { \& Solubility }\end{array}$ & Product & Species & $\begin{array}{l}\text { Titer } \\
\text { (g/L) }\end{array}$ & $\begin{array}{l}\text { Producti } \\
\text { (g/L-h) }\end{array}$ & Yield & Co-products & Reference \\
\hline $\begin{array}{l}\text { Intra- } \\
\text { cellular } \\
\text { (insoluble) }\end{array}$ & $\begin{array}{l}\text { Lipids, PHA's } \\
(25-80 \% \\
\text { CDW) }\end{array}$ & $\begin{array}{l}\text { Bacteria }(A . \\
\text { latus), Yeast } \\
\text { (C. laurentii) }\end{array}$ & $10-200$ & $0.01-2.5$ & $\begin{array}{l}0.1-0.3 \mathrm{~g} / \mathrm{g} \\
\text { on different } \\
\text { substrates }\end{array}$ & Organic acids & $\begin{array}{l}\text { (Castanha et al., } \\
\text { 2013; Choi and } \\
\text { Lee, 1997) }\end{array}$ \\
\hline $\begin{array}{l}\text { Intra- } \\
\text { cellular } \\
\text { (soluble) }\end{array}$ & $\begin{array}{l}\text { Proteins } \\
(2-70 \% \mathrm{CDW})\end{array}$ & $\begin{array}{l}\text { Bacteria (E. } \\
\text { coli), Yeast, } \\
\text { Archaea }\end{array}$ & $5-268$ & $0.01-6.6$ & various & $\begin{array}{l}\text { Similar } \\
\text { proteins }\end{array}$ & $\begin{array}{l}\text { (Hatti-Kaul and } \\
\text { Mattiasson, 2003; } \\
\text { Riesenberg and } \\
\text { Guthke, 1999) }\end{array}$ \\
\hline $\begin{array}{l}\text { Extra- } \\
\text { cellular } \\
\text { (organic/ } \\
\text { insoluble) }\end{array}$ & Fatty alcohols & $\begin{array}{l}\text { Bacteria } \\
\text { (E. coli) }\end{array}$ & 1.6 & 0.01 & $\begin{array}{l}0.13 \mathrm{~g} / \mathrm{g} \\
\text { glucose }\end{array}$ & $\begin{array}{l}\text { Fatty acids, } \\
\text { acetate }\end{array}$ & $\begin{array}{l}\text { (Youngquist et al., } \\
\text { 2013) }\end{array}$ \\
\hline $\begin{array}{l}\text { Extra- } \\
\text { cellular } \\
\text { (aqueous/ } \\
\text { soluble) }\end{array}$ & $\begin{array}{l}1,3- \\
\text { propanediol }\end{array}$ & $\begin{array}{l}\text { Bacteria } \\
(C . \\
\text { butyricum, E. } \\
\text { Coli, } K \text {. } \\
\text { pneumoneae })\end{array}$ & $35-80$ & $1.5-3$ & $\begin{array}{l}0.72-0.88 \\
\mathrm{~mol} / \mathrm{mol} \\
\text { glycerol }\end{array}$ & $\begin{array}{l}\text { Ethanol, } \\
\text { lactic acid, } \\
\text { succinic acid, } \\
\text { butanediol }\end{array}$ & $\begin{array}{l}\text { (Zeng and Biebl, } \\
\text { 2002) }\end{array}$ \\
\hline
\end{tabular}

${ }^{*} \mathrm{CDW}$ - cell dry weight

When a chemical of interest is produced by the cell, it is then localized either inside the cell or released in the extracellular phase through a combination of active and passive processes. In addition to localization, the solubility in water helps in defining four type of chemicals (1) intracellular insoluble (i.e. aggregates in an inclusion body or insoluble storage granules), (2) intracellular soluble (i.e. soluble metabolites), (3) extracellular insoluble (i.e. insoluble solids or organic liquids), or (4) extracellular soluble in the aqueous medium (i.e. secreted metabolites). Most products are initially produced intracellularly in the cell cytoplasm and elevated concentrations of these molecules can provide negative feedback on production pathways and/or negatively impact cell physiology (Jones et al., 2015). Some high molecular weight products, such as polyhydroxyalkanoates (PHAs) or glycogen, aggregate inside the cell (Agnew et al., 2012; Aikawa et al., 2014). Some products are localized extracellularly to the aqueous medium through passive diffusion or through active transport by protein transporters (Jones et al., 2015). Depending on chemical equilibrium, products with low water-solubility may partition into an organic phase; this process can be facilitated through co-culturing with a metabolically inert organic phase (Daugulis, 2001; Janssen et al., 2015; Martin et al., 2003). The final localization, water solubility and concentration of product will largely determine the downstream separation technologies as discussed in section 7 . 
Table 2 Sample metrics for photoautotrophic microbial processing route with details about product localization, microbial species, typical biomass titers, productivity, yields and potential co-products.

\begin{tabular}{|c|c|c|c|c|c|c|c|}
\hline \multicolumn{2}{|c|}{ Energy Source } & \multicolumn{2}{|l|}{ Carbon Source } & \multicolumn{2}{|c|}{ Biomass Titer } & \multicolumn{2}{|c|}{ Biomass Productivity } \\
\hline \multicolumn{2}{|l|}{ Light } & \multicolumn{2}{|c|}{$\begin{array}{l}\text { Inorganic Carbon } \\
\left(\mathrm{CO}_{2} \text { and } \mathrm{HCO}_{3}^{-}\right)\end{array}$} & \multicolumn{2}{|c|}{$\begin{array}{l}\text { Low } \\
(0.1-10 \mathrm{~g} / \mathrm{L})\end{array}$} & \multicolumn{2}{|c|}{$\begin{array}{l}\text { Low } \\
(0.002-0.2 \mathrm{~g} / \mathrm{L}-\mathrm{h})\end{array}$} \\
\hline $\begin{array}{l}\text { Localization } \\
\text { \& Solubility }\end{array}$ & Product & Species & $\begin{array}{l}\text { Titer } \\
\text { (g/L) }\end{array}$ & $\begin{array}{l}\text { Productiv } \\
\text { (g/L-h) }\end{array}$ & Yield & $\begin{array}{l}\text { Co- } \\
\text { products }\end{array}$ & Reference \\
\hline $\begin{array}{l}\text { Intra- } \\
\text { cellular } \\
\text { (insoluble) }\end{array}$ & $\begin{array}{l}\text { Oils, glycogen } \\
(39-70 \% \\
\text { CDW) }\end{array}$ & $\begin{array}{l}\text { Algae } \\
\text { (C. vulgaris, } \\
\text { B. braunii, } \\
\text { S. acutus, } \\
\text { P. incisa) } \\
\text { Cyanobacteria } \\
\text { (Synechococcus, } \\
\text { Synechocystis) }\end{array}$ & $0.1-10$ & $0.002-0.2$ & $\mathrm{~N} / \mathrm{A}$ & $\begin{array}{l}\text { Secondary } \\
\text { metabolites }\end{array}$ & $\begin{array}{l}\text { (Aikawa et al., } \\
\text { 2014; Li et al., } \\
\text { 2008) }\end{array}$ \\
\hline $\begin{array}{l}\text { Intra- } \\
\text { cellular } \\
\text { (soluble) }\end{array}$ & $\begin{array}{l}\text { Proteins, B- } \\
\text { phycoerythrin } \\
(2-70 \% \mathrm{CDW})\end{array}$ & $\begin{array}{l}\text { Algae (P. } \\
\text { cruentum), } \\
\text { Cyanobacteria } \\
\text { (Synechococcus, } \\
\text { Synechocystis) }\end{array}$ & $0.1-10$ & $0.002-.2$ & $\mathrm{~N} / \mathrm{A}$ & $\begin{array}{l}\text { Similar } \\
\text { proteins, } \\
\text { secondary } \\
\text { metabolites }\end{array}$ & $\begin{array}{l}\text { (Ruiz-Ruiz et al., } \\
\text { 2013) }\end{array}$ \\
\hline $\begin{array}{l}\text { Extra- } \\
\text { cellular } \\
\text { (organic/ } \\
\text { insoluble) }\end{array}$ & Fatty alcohols & $\begin{array}{l}\text { Cyanobacteria } \\
\text { (Synechocystis } \\
\text { sp. PCC 6803) }\end{array}$ & 0.002 & 0.000005 & $\mathrm{~N} / \mathrm{A}$ & $\begin{array}{l}\text { Fatty acids, } \\
\text { secondary } \\
\text { metabolites }\end{array}$ & (Yao et al., 2014) \\
\hline $\begin{array}{l}\text { Extra- } \\
\text { cellular } \\
\text { (aqueous/ } \\
\text { soluble) }\end{array}$ & $\begin{array}{l}\text { 1,3- } \\
\text { propanediol }\end{array}$ & $\begin{array}{l}\text { Cyanobacteria } \\
\text { (S. elongatus } \\
\text { sp. PCC 7942) }\end{array}$ & 0.29 & 0.0005 & $\mathrm{~N} / \mathrm{A}$ & $\begin{array}{l}\text { Glycerol, } \\
\text { secondary } \\
\text { metabolites }\end{array}$ & $\begin{array}{l}\text { (Hirokawa et al., } \\
\text { 2016; Wang et al., } \\
\text { 2001) }\end{array}$ \\
\hline
\end{tabular}

*CDW - cell dry weight, N/A - not applicable

The composition of impurities will also have significant impact on downstream processing. Process streams will contain the targeted chemical, coproducts as well as components of biomass, including lipids, proteins, and other organism specific biomolecules (Wang et al., 2013). The concentrations of these impurities can be minimized by metabolic engineering and bioreactor engineering to maximize the yield of desired product on the substrate of choice. In Figure 1 we present the important features of upstream processing. We believe that prior information about these features will provide valuable insights for efficient designing of the downstream separation system. 


\section{Downstream processing}

There are multiple technology alternatives available for performing separation tasks. Every technology has a specific driving force and a key cost driver which determines its efficiency and economic contribution to the overall costs. Integration of information from upstream processing, technology options and commercial requirements along with the application of process evaluation methods can help in successful engineering of a separation process (Han et al., 2015; Kim et al., 2013; Wu et al., 2016).

\subsection{Design considerations}

The first step in designing a downstream process is to characterize the stream coming from upstream processing. The factors essential for this are as follows (Nfor et al., 2008):

- Product concentration (titer) and properties

- Localization of the product, as described in subsection 2.3

- Complexity of the stream in terms of number of components and their properties

- Presence of critical contaminants

- Susceptibility of components to degradation, sensitivity to $\mathrm{pH}$, light, shear, organic solvents, and temperature

- Stream flow rate, which affects the scale of the process

The design stage is heavily dependent on information available from past literature, knowledgebased heuristics and simulation studies (Asenjo and Andrews, 2008; Backhaus et al., 2015; Lienqueo and Asenjo, 2000; Petrides, 2013; Steffens et al., 2000). Thus, information from upstream aspects discussed in section 2 can play a vital role in characterizing the potential streams and designing separation systems for novel chemicals. Also, identification of physicochemical properties (Carlson, 1996; van Hee et al., 2006) by utilizing information from existing databases (NIST, ChemSpider, PubChem, DIPRR) and group contribution methods (Constantinou and Gani, 1994; Gani et al., 1991; Joback and Reid, 1987; Lymperiadis et al., 2008; Mavrovouniotis, 1990; Papaioannou et al., 2011; Sheldon et al., 2005) can help in the initial studies.

The downstream separation network involves many technology options. The number, $N_{f}$, of distinct separation networks for a stream containing $C$ components, to be separated into $C$ pure component streams, is given by eq. (2) (Chisti, 1998),

$$
N_{f}=\frac{[2(C-1)] ! S^{(C-1)}}{C !(C-1) !}
$$

where, $S$ is the number of technologies available for each separation task.

While this number grows combinatorically, some flowsheets may be undesirable; for example, the option to use filtration without pretreatment for solid particles of size less than $70 \mu \mathrm{m}$. Furthermore, casespecific information should be accounted for; for example, precipitation should be an option after product 
solubilization if the desired product is to be recovered in solid state (Shimoni et al., 2013; Todaro and Vogel, 2014; Wang and Singh, 2013). Another consideration could be about biosafety (Vranch et al., 1992); e.g., for products which are potentially allergenic and co-products and impurities that are toxic. The technology options in the final steps depend on product specifications; e.g., purity requirements, desired physical form, stability, and bio-viability. Hence, technology limitations, case-specific considerations, product specifications, prior information from upstream processing (discussed in section 2) and engineering judgement can help in reducing the number of potential flowsheets. These pre-selected flowsheets can be further screened using heuristics of evaluated using detailed techno-economic studies (Davis et al., 2011; Gnansounou and Dauriat, 2010; Hamelinck et al., 2005).

\subsection{Separation technologies}

The following five heuristics rules have been suggested (Asenjo, 1990; Harrison et al., 2003) for efficient recovery of bio-based products.

1) Separate the most plentiful impurities first

2) Remove the easiest-to-remove impurities first

3) Do the most difficult and expensive step at the end

4) Choose separation technologies based on different physical and chemical properties

5) Select and sequence technologies that exploit different separation driving forces

Separation technologies either use a mass separating agent (MSA) (addition of mass in the form of another component) or an energy separating agent (ESA) (addition of energy in the form of heat or work) (Afonso and Crespo, 2006) or a combination of both to separate the desired product from other process stream constituents. MSAs can be in solid, liquid or gaseous state and are characterized by their capacity to incorporate the desired product and its selectivity for the product as compared to other components. ESAs used are heating, cooling, work and external field forces such as electric and gravity and are characterized by the amount of energy required to achieve a certain degree of separation and selectivity in a given process. For higher product recovery, usually ESA technologies (no added component and usually one step) are preferred over MSA technologies (e.g. extraction, adsorption and precipitation) which require further steps for product recovery and MSA recycling (Shukla et al., 2006).

\subsection{Separation stages}

The recovery of bio-based chemicals can be broadly divided into three stages: (I) Cell and product isolation, (II) Product concentration, and (III) Product purification and refinement. Each stage can have multiple technology options for performing similar tasks. In Figure $\mathbf{2}$ we present a schematic of the three stage separation framework and list the possible technology options which are reviewed in sections 4, 5, and 6. In Figure 3 we represent the flow of the process stream into the different tasks involved in each 
stage. The order in which these tasks should be performed as well as details regarding the essential and optional tasks is also included.

\section{Stage I - Cell and product isolation}

In this stage, cell harvesting (intracellular products) or cell removal (extracellular products) is the foremost task. It involves solid-liquid separation and each technology option utilizes differences in physical properties, such as size, shape, density and shear effects of the components involved. Table 3 enlists some characteristics for different types of cells and these play a major role in shortlisting the prospective technologies. In some cases, process stream may require pretreatment to facilitate separation of cells, such as heat treatment, $\mathrm{pH}$ and ionic strength adjustments, or addition of filter aids, coagulants and flocculants. This helps in enhancing gradients in the key separation properties, thus making the cell harvesting/removal task more efficient.

Table 3 Characteristics of different types of cells or biomass*

\begin{tabular}{lllll}
\hline Cells/Biomass & Shape & Size $(\boldsymbol{\mu m})$ & Density $(\mathbf{k g} / \mathbf{m} 3)$ & Shear resistance \\
\hline \multirow{2}{*}{ Bacteria } & Rods & $0.5-3$ & $1050-1080$ & Good \\
& Cocci & $5-10$ & $1050-1090$ & Good \\
Yeast & Spherical & $5-10$ & $1050-1090$ & Good \\
Fungi & Filamentous & $20->100$ & $1050-1090$ & Fair \\
Plants & Irregular & $20-100$ & $1050-1090$ & Poor \\
Debris & Varied & $<1$ & $1010-1200$ & Poor \\
\hline
\end{tabular}

* adapted from (Verrall, 1996)

Based on product localization, either the biomass rich stream (in case of intracellular products) or the aqueous product containing stream (in case of extracellular products) will be considered for further processing. For intracellular products, the cell harvesting task is followed by cell disruption to release the desired product. The rupturing of cells has to be carried out in a manner so as to recover the product in its active form. Due to these restrictions, recovery of intracellular products can become more challenging (Kennedy and Cabral, 1993). The resultant stream after disruption needs a phase isolation task to separate the product from remaining water, cell debris and other intracellular constituents. For extracellular products, cell removal may be followed by another phase isolation based on product content and properties of the product containing stream. Also, the cells removed can be recycled back to microbial cultivation reactors if they are viable. In the following subsections, we provide a brief description of technologies available in stage-I for the different tasks of pretreatment, cell harvesting/removal, cell disruption and phase isolation.

\subsection{Pretreatment}


Pretreatment enhances the efficiency of cell harvesting/removal technologies by formation of cell aggregates or flocs, thus increasing their effective settling or filtering size. This can be achieved by several methods, such as $\mathrm{pH}$ adjustments, addition of electrolytes or polymers.

\subsubsection{Coagulation}

Coagulation can be achieved by $\mathrm{pH}$ change or electrolyte addition. Cell surfaces are usually negatively charged under normal fermentation conditions. The surface charge is a function of hydrogen ion concentration and hence if the $\mathrm{pH}$ is reduced to a certain value, it will reduce the negative charge on the cell surface, thus enabling their coagulation. Majority of biomass will have a zero surface charge within a $\mathrm{pH}$ range of 4.5 to 6.5 (Verrall, 1996). Thus, the acid required to reach the pH range and efficient mixing (Rossini et al., 1999) are the cost drivers in pH induced coagulation. The electrostatic repulsion forces of biomass can be reduced by addition of electrolytes (Lee et al., 2013). The higher the opposite charge to the biomass the greater is the effect of the electrolyte addition. Thus, the typical electrolytes used for coagulation are salts including nitrates and chlorides (Ryu et al., 1996), calcium, magnesium, ferrous, ferric and aluminum.

\subsubsection{Flocculation}

Polymers adsorb on the surface of the biomass to enable flocculation. Polymeric flocculants can be of natural origin such as starches, celluloses, alginates and chitins or synthetic such as acrylamide and acrylates. Chitosan is an edible, nontoxic flocculent which is very effective for different types of microalgae and requires low doses (Molina Grima et al., 2003). The important properties (Shuler \& Kargi, 1992) to be considered in flocculation are the flocculent concentration, concentration of biomass, floc-formation kinetics, floc size and its effect on the separation rate in the following unit operations. The flocculent doses (Atkinson and Mavituna, 1991) can range from 0.04 - $200 \mathrm{~g}$ per $100 \mathrm{~g}$ cell dry weight (CDW) and for dilute broths the lower range values are used. The average floc-size for bacterial cells on flocculent addition has been reported to be in the range of $100-250 \mu \mathrm{m}$ (Luna et al., 2005).

\subsection{Cell harvesting/removal}

Cell harvesting or removal is mainly composed of all solid-liquid separation technologies such as sedimentation, centrifugation, filtration, flotation and ultrasonic separation. The low resolution membrane separation of microfiltration (detailed description in subsection 4.4.3) is also widely used for cell harvesting/removal when the cell size is small or pretreatment methods are not viable.

\subsubsection{Sedimentation}

Sedimentation is solid-liquid separation under the influence of gravity. It is dependent on the properties of the solids such as their shape, size, and density and the liquid such as its density and viscosity. When the frictional force and buoyant force balance the gravitational force, the resulting velocity at which 
the particles move downwards is known as their terminal settling velocity. As the concentration of the sedimenting particles tends to increase, the settling velocity tends to decrease, this phenomenon is known as 'hindered settling' (Harrison et al., 2003; Najafpour, 2015). The hindered settling velocity is dependent upon the particle shape and concentration in the liquid. The key factor is the speed of settling, which should be more than the liquid flowrate from the sedimentation tank's inlet to outlet (a.k.a. the surface overflow rate). Thus, sedimentation tanks require larger residence times increasing the overall dimensions of the unit (Harker et al., 2002).

\subsubsection{Centrifugation}

The centrifugal force is used to separate solid particles from liquid in a centrifuge. The expression for terminal separation velocity in centrifugation is related to the settling velocity in gravity sedimentation; the gravitational acceleration is replaced by the centrifugal acceleration. Hindered settling under high solids concentration is also applicable to centrifugation and is a function of the shape and concentration levels of the solids. The soluble components are distributed uniformly in the exiting streams of the centrifuge. The capacity to handle a given flowrate of the process stream and settling distance for capturing the particles are important parameters in design of a centrifuge (Shuler \& Kargi, 1992). A centrifugation coefficient or sigma factor ' $\Sigma$ ' for a centrifuge is equivalent to the surface area of a gravity sedimentation tank to achieve the same separation performance as that of the centrifuge (Ambler, 1961). The centrifugation coefficient is used while designing different types of centrifuges such as bowl, tubular and disc-stack (Salte et al., 2006). It is also used for scale-up purposes when the same solid-liquid system is involved.

\subsubsection{Filtration}

Filtration is used to separate solids or particulate matter from a liquid using a filter medium. Filtration is fairly simple and efficient for large sized well-defined particles however, it becomes difficult as the particle size decreases. The deformable nature of biological materials adds to the complexity. Thus, filtration applications in separation require some modifications in the properties of the particulate matter which are retained on the surface of the filter medium, such as addition of filter aids for particle aggregation. Filtration equipment (Belter et al., 1988) are usually designed for batch mode of operation such as plate and frame filter, leaf filter and candle filter and require regular cleaning and maintenance thus making them labor intensive. For continuous operation, the rotary vacuum filters are more common and are widely used in separations. These are automated and can be operated on large scale commercially. They are particularly useful when the filtration is slow and difficult. For microbial separations, the cell size should be relatively large $(\sim 70 \mu \mathrm{m})$ and if it is less than $30 \mu \mathrm{m}$, filtration cannot be used without applying pretreatment methods to increase the effective particle size (Brennan and Owende, 2010).

\subsubsection{Flotation}


Flotation (Hanotu et al., 2012; Najafpour, 2015) is useful when the process stream is composed of hydrophobic colloidal size range particles. This is achieved by introducing fine gas bubbles into the liquid phase which attach to these hydrophobic particles forming buoyant aggregates which rise to the surface in the flotation system. This method is particularly attractive for organic and low density products such as oils and incase of water scarcity. The important factors for a flotation system include hydrophobic nature and concentration of particulate matter, air quantity used, particle density and solids loading rate. In case of dissolved air flotation (DAF), air is dissolved into the aqueous system under pressure of several atmospheres. This makes the solution supersaturated which leads to nucleation of the microbubbles as soon as the pressure gradient is reduced. However, the process is energy intensive due to high pressure and pumping power required and is suitable for limited types of microbes and biological products. Also, there is very limited information about its technical and economic viability on large scale (Brennan and Owende, 2010).

\subsubsection{Ultrasonic separation}

Ultrasound along with enhanced sedimentation can be used for harvesting/removal of cells from aqueous broth. The broth is pumped continuously into a resonating chamber which consists of a transducer and a reflector. The chamber size is such that a standing wave occurs. The ultrasonic waves create fields of maximum (bellies) and minimum (nodes) potential energy. Time averaged radiation forces on the cells drive them instantly to the node planes. The cell-cell interaction in the ultrasonic field results in attractive forces between cells which drive them together to form agglomerates. On nullification of the ultrasonic field, these larger agglomerates then sediment rapidly by gravity forces (Bosma et al., 2003; Coakley et al., 1994; Show et al., 2013).

\subsection{Cell disruption}

Cell disruption is a key unit operation in the recovery of intracellular products. The methods involved in cell disruption can be categorized into two types - mechanical and non-mechanical. The nonmechanical methods can be further sub-categorized as physical, chemical and biological methods based on the forces or medium involved (Günerken et al., 2015; Harrison, 1991).

\subsubsection{Mechanical methods}

These methods may involve solid or liquid shear based on the medium in which cells are suspended. The disadvantage can be high capital investment and energy costs, protein inactivation due to shear associated denaturation and excessive heating because of energy dissipation. Bead mill is one of the most widely used mechanical disruption option wherein grinding and dispersion occur due to inter-particle collision and solid shear effects. The bead mill consists of either a vertical or horizontal grinding chamber containing agitators of varying designs such as concentric discs, rings or impellers mounted on motor driven shaft that can export kinetic energy to small beads which are made of steel, glass or ceramic, thus 
resulting in multiple collisions. Horizontal units are better because fluidizing effects can occur in vertical columns. The performance is influenced by range of parameters, such as number and energy of impacts taking place, energy transfer to grinding elements, liquid shear, hydrodynamics and mixing, bead diameter, density, loading, cell concentration in feed, flow rate, agitator speed, configuration, geometry and temperature. The cell breakage follows first order kinetics. Another method, high pressure homogenization (HPH) employs various types of valve and impactor arrangements for desired disruption efficiency and is most widely used for large scale cell disruption. The cell suspension flows radially across the valve, strikes the impactor and then exits the unit or flows to a second valve in case of multiple pass homogenizer. Cell breakage occurs due to high-pressure impact of the flowing fluid on the valve surface and hydrodynamic cavitation from the shear forces due to pressure drop (Chisti and Moo-Young, 1996). The protein release kinetics was observed to be first order with respect to number of passes through the homogenizer. Ultrasonic vibrations and microwave radiations can also be used to disrupt cells. Ultrasonic vibrations (Günerken et al., 2015) emitted can result in acoustic cavitation. The microwaves cause thermolysis of water which results in cavitation. These can result into micro-regions of extreme conditions with very high temperatures and pressures. Thus, temperature control is essential for better product recovery and quality. However, these methods have low disruption efficiency and are usually combined with other methods.

\subsubsection{Physical methods}

Methods such as osmotic shock, temperature extremes and desiccation are categorized into physical disruption methods. Slowly freezing and then thawing the cells can break the cell wall and membrane, releasing enzymes in the media. Osmotic pressure change of the medium can release specific enzymes (Shuler and Kargi, 1992).

\subsubsection{Chemical methods}

Cell disruption can occur by different types of chemical compounds such as antibiotics, chelating agents, chaotropic agents, detergents, solvents, hypochlorites, acids and alkalis. The suitability of these compounds depends upon type of cells and their cell wall composition (Günerken et al., 2015). Acid treatment at high temperature $\left(58-160{ }^{\circ} \mathrm{C}\right)$ leads to high degree of cell disruption (Miranda et al., 2012). When cells are exposed to alkaline $\mathrm{pH}$ in the range of 11.5 - 12.5 for 20 to 30 minutes it results in cell lysis. Chemicals such as urea and guanidine hydrochloride are mediators of cell lysis (Harrison, 1991). Guanidine hydrochloride can solubilize protein from E.coli membrane fragments by altering the hydrophobicity of the aqueous medium. Bacterial cells in the presence of detergents such as sodium dodecyl sulfate (SDS) release cellular constituents and this is a well-established method in molecular biology.

\subsubsection{Biological methods}


Enzymatic cell lysis can maintain biological specificity and its features are mild operating conditions and low energy requirements. The major classes of lytic enzymes are glycosidases, glucanases, peptidases and lipases and are used selectively for different types of micro-organisms. From enzyme kinetics, both cell and enzyme concentrations are critical factors in determining the performance of lysis. Thus, biomass to enzyme ratio can be optimized for efficient operation and higher product release, which can be as high as 90-95\% (Ho et al., 2013). Cell wall synthesis may be blocked by inhibition of required enzymes or by addition of antibiotics such as penicillin. Certain antibiotics permeabilize the bacterial cells but do not cause its lysis, thus enabling selective product release.

\subsubsection{Summary of cell disruption methods}

The technologies in each disruption method, operating conditions with regards to product susceptibility to denaturation, range for product release efficiency and costs, and some drawbacks are listed in Table 4. Sometimes, combination of these methods can be used for higher product release efficiency.

Table 4 Summary of cell disruption methods

\begin{tabular}{|c|c|c|c|c|c|c|}
\hline $\begin{array}{l}\text { Disruption } \\
\text { method }\end{array}$ & Technologies & $\begin{array}{l}\text { Operating } \\
\text { conditions }\end{array}$ & $\begin{array}{l}\text { Product release } \\
\text { efficiency }\end{array}$ & Cost range & Drawbacks & References \\
\hline Mechanical & $\begin{array}{l}\text { Bead mill, HPH, } \\
\text { ultrasonication } \\
\text { and microwaves }\end{array}$ & $\begin{array}{l}\text { ESA (power, } \\
\text { pressure, } \\
\text { radiations) } \\
\text { Harsh to } \\
\text { moderate } \\
\text { conditions } \\
\text { Possibility of } \\
\text { product } \\
\text { degradation }\end{array}$ & $\begin{array}{l}\text { Bead mill } 70 \text { to } \\
95 \% \\
\text { HPH } \sim 67 \text { to } \\
91 \%, \mathrm{HPH} \\
\text { requires dilute } \\
\text { feed }\end{array}$ & $\begin{array}{l}\text { Moderate } \\
\text { to high } \\
\text { costs }\end{array}$ & $\begin{array}{l}\text { More utility } \\
\text { requirement } \\
\text { Heat dissipation } \\
\text { No product } \\
\text { selectivity }\end{array}$ & $\begin{array}{l}\text { (Balasundaram } \\
\text { et al., 2009; } \\
\text { Günerken et al., } \\
\text { 2015; Melendres } \\
\text { and Unno, 1992; } \\
\text { Postma et al., } \\
\text { 2015; van Hee et } \\
\text { al., 2006) }\end{array}$ \\
\hline Physical & $\begin{array}{l}\text { Osmotic shocks, } \\
\text { freezing and } \\
\text { thawing }\end{array}$ & $\begin{array}{l}\text { ESA(cooling, } \\
\text { pressure } \\
\text { gradients) } \\
\text { Low stress }\end{array}$ & Low efficiency & Low costs & $\begin{array}{l}\text { Lab scale } \\
\text { method } \\
\text { Scale-up and } \\
\text { control } \\
\text { difficulties }\end{array}$ & $\begin{array}{l}\text { (Chisti and Moo- } \\
\text { Young, 1996; } \\
\text { Günerken et al., } \\
\text { 2015) }\end{array}$ \\
\hline Chemical & $\begin{array}{l}\text { Acid hydrolysis, } \\
\text { surfactant } \\
\text { treatment }\end{array}$ & $\begin{array}{l}\text { MSA(acids, } \\
\text { alkalis, } \\
\text { detergents) } \\
\text { Mixing rate, } \\
\text { temperature }\end{array}$ & $\begin{array}{l}\text { Acid lysis } \sim 75 \text { to } \\
92 \% \\
\text { Product } \\
\text { selectivity }\end{array}$ & $\begin{array}{l}\text { Low to } \\
\text { moderate } \\
\text { costs }\end{array}$ & $\begin{array}{l}\text { Difficulty in } \\
\text { recovery of acid } \\
\text { or alkali }\end{array}$ & $\begin{array}{l}\text { (Miranda et al., } \\
\text { 2012; Sarada et } \\
\text { al., 2006) }\end{array}$ \\
\hline Biological & Enzyme lysis & $\begin{array}{l}\text { MSA(enzyme) } \\
\text { Gentle and low } \\
\text { stress } \\
\text { Biological } \\
\text { specificity }\end{array}$ & $\begin{array}{l}\text { Enzyme lysis } ~ 90 \\
\text { to } 95 \% \\
\text { Product } \\
\text { selectivity }\end{array}$ & $\begin{array}{l}\text { Moderate } \\
\text { to high } \\
\text { costs }\end{array}$ & $\begin{array}{l}\text { Not widely used } \\
\text { in industries } \\
\text { Enzyme } \\
\text { availability }\end{array}$ & $\begin{array}{l}\text { (Andrews and } \\
\text { Asenjo, 1987; } \\
\text { Babu and } \\
\text { Choudhury, } \\
\text { 2013; Günerken } \\
\text { et al., 2015) }\end{array}$ \\
\hline
\end{tabular}

\subsection{Phase isolation}


Phase isolation can be performed by the previously mentioned technologies such as sedimentation, centrifugation, filtration, flotation, microfiltration, ultrasonic separation and additional technologies of solubilization, differential digestion and other membranes such as ultrafiltration, reverse osmosis and nanofiltration.

\subsubsection{Solubilization}

Solubilization can be used for phase isolation in case of intracellular (IN) as well as extracellular (EX) products. It is used to dissolve a product in a solvent, which is selective towards the product and does not dissolve the other co-products and impurities present in the stream (Epp and Fetterolf, 2009). Selective solubilization (Singh and Panda, 2005) can also be achieved by adjusting conditions such as $\mathrm{pH}$ and temperature of the mixture containing the target molecule in rare cases. This is particularly effective when the targeted molecule has an effective charge and its solubility is sensitive to $\mathrm{pH}$ changes.

\subsubsection{Differential digestion}

Differential digestion is specific to intracellular (IN) products and involves the dissolution of nonproduct cellular materials (NPCM) using surfactants, enzymes, alkalis, acids or a combination of these agents. This method is advantageous when the desired product is polymeric in nature (Choi and Lee, 1999) because polymeric solutions tend to become viscous and solubilization of large molecules may become difficult. The molecular weight of the polymeric product recovered is dependent upon the type of dissolution agent used. The use of a surfactant such as sodium hypochlorite can reduce the molecule weight of the original polymeric product by $50 \%$ (Sayyed et al., 2009). The use of enzymes can prevent this reduction in molecular weight, but are not preferred because of their high cost and multiple recovery steps involved. Thus, the digestion agent(s) is (are) selected based on the process economics, product properties, its yield and purity requirements.

\subsubsection{Membranes}

These involve semi-permeable membranes and pressure driving force for the separation of components in a solution or colloidal dispersion. Depending upon particle or molecular size the membrane processes used are microfiltration (MF), ultrafiltration (UF), nanofiltration (NF) and reverse osmosis (RO) as shown in Figure 4 (Ho and Sirkar, 1992; Lewis, 1996; van Reis and Zydney, 2007, 2001; Yoon, 2015). Other factors affecting the separation efficiency are average flux through the membrane, hydrostatic pressure gradient $(\Delta \mathrm{P})$, membrane pore size, fouling characteristics, molecular weights, charge, shape and concentration of components in process stream (Verrall, 1996). The retention ratio, defined as one minus the ratio of permeate (passes through membrane) to retentate (blocked by membrane) concentration, is the efficiency measure for membrane processes. The particles which are desired to be retained by the membrane should have a retention ratio closer to 1 (Koros et al., 1996). Membrane processes are used for 
several objectives such as removal of cells and cell debris, concentration of cells or proteins and removal of specific solutes (Harrison et al., 2003).

\subsection{Summary of separation technologies in stage $I$ - Cell and product isolation}

The details regarding separation principle (driving force), important conditions, technology performance parameters (when applicable) in terms of product recovery efficiency, some advantages and drawbacks are summarized in Table 5 for stage I technologies.

Table 5 Summary of separation technologies in stage I - Cell and product isolation

\begin{tabular}{|c|c|c|c|c|c|c|}
\hline echnology & $\begin{array}{l}\text { Principle/ } \\
\text { Driving force }\end{array}$ & $\begin{array}{l}\text { Important } \\
\text { conditions }\end{array}$ & $\begin{array}{l}\text { Performance } \\
\text { parameters }\end{array}$ & Advantages & Drawbacks & References \\
\hline Flocculation & $\begin{array}{l}\text { Additives } \\
\text { Collision rate } \\
\text { MSA (polymer) }\end{array}$ & $\begin{array}{l}\text { Uniform } \\
\text { flocculent } \\
\text { distribution } \\
\text { Mixing rate } \\
\text { Amount required }\end{array}$ & $\begin{array}{l}\text { Floc size to } \\
\text { particle size } \\
\text { ratio } \sim 8-12\end{array}$ & $\begin{array}{l}\text { Does not affect } \\
\text { product or } \\
\text { biomass } \\
\text { properties }\end{array}$ & $\begin{array}{l}\text { Cost of } \\
\text { flocculants } \\
\text { Recovery and } \\
\text { recycling }\end{array}$ & $\begin{array}{l}\text { (Elmaleh and } \\
\text { Jabbouri, 1991; } \\
\text { Lee et al., 2010; } \\
\text { Morrissey et al., } \\
\text { 2015; } \\
\text { Salehizadeh and } \\
\text { Shojaosadati, } \\
\text { 2001; } \\
\text { Vandamme et al., } \\
\text { 2013) }\end{array}$ \\
\hline Coagulation & $\begin{array}{l}\text { pH } \\
\text { Charge } \\
\text { MSA(acid or } \\
\text { electrolyte) }\end{array}$ & $\begin{array}{l}\text { Coagulant } \\
\text { distribution } \\
\text { Product stability } \\
\text { at pH conditions }\end{array}$ & $\begin{array}{l}\text { Depends on } \\
\text { ionic charge of } \\
\text { electrolytes } \\
\text { and pH range }\end{array}$ & $\begin{array}{l}\text { Increase in } \\
\text { effective } \\
\text { particle size }\end{array}$ & $\begin{array}{l}\text { High doses } \\
\text { required } \\
\text { Biomass or } \\
\text { product } \\
\text { properties } \\
\text { can be altered }\end{array}$ & $\begin{array}{l}\text { (Lee et al., 2013; } \\
\text { Rossini et al., } \\
\text { 1999; Verrall, } \\
\text { 1996) }\end{array}$ \\
\hline edimentation & $\begin{array}{l}\text { Settling velocity } \\
\text { ESA(gravity) }\end{array}$ & $\begin{array}{l}\text { Surface overflow } \\
\text { rate less than } \\
\text { settling velocity }\end{array}$ & $\begin{array}{l}\text { Product } \\
\text { recovery } \\
\text { efficiency } \sim 40 \\
\text { to } 80 \%\end{array}$ & $\begin{array}{l}\text { Physical } \\
\text { separation } \\
\text { process } \\
\text { No utility } \\
\text { requirement }\end{array}$ & $\begin{array}{l}\text { More } \\
\text { equipment } \\
\text { area } \\
\text { Time } \\
\text { consuming }\end{array}$ & $\begin{array}{l}\text { (Bahadori et al., } \\
\text { 2013; Bautista et } \\
\text { al., 1986; Harker } \\
\text { et al., 2002; Luna } \\
\text { et al., 2005; } \\
\text { Machmudah et } \\
\text { al., 2006) }\end{array}$ \\
\hline ion & $\begin{array}{l}\text { Settling velocity } \\
\text { ESA(centrifugal } \\
\text { force) }\end{array}$ & $\begin{array}{l}\text { High centrifugal } \\
\text { to gravitational } \\
\text { force ratio } \\
\text { Settling distance }\end{array}$ & $\begin{array}{l}\text { Product } \\
\text { recovery } \\
\text { efficiency } \sim 40 \\
\text { to } 96 \%\end{array}$ & $\begin{array}{l}\text { Faster } \\
\text { separation } \\
\text { Widely used }\end{array}$ & $\begin{array}{l}\text { High capital } \\
\text { and utility } \\
\text { costs }\end{array}$ & $\begin{array}{l}\text { (Ambler, 1961; } \\
\text { Molina Grima et } \\
\text { al., 2003; Salte et } \\
\text { al., 2006; Shuler } \\
\text { and Kargi, 1992) }\end{array}$ \\
\hline Filt & $\begin{array}{l}\text { Particle size } \\
\text { Pressure } \\
\text { gradient } \\
\text { MSA(filter) }\end{array}$ & $\begin{array}{l}\text { Average flux } \\
\text { Filtration rate } \\
\text { Relatively larger } \\
\text { particle size }>70 \\
\mu \mathrm{m}\end{array}$ & $\begin{array}{l}\text { Product } \\
\text { recovery } \\
\text { efficiency } \sim 85 \\
\text { to } 96 \%\end{array}$ & $\begin{array}{l}\text { High } \\
\text { concentration } \\
\text { factor } \\
\text { Limited utility } \\
\text { costs }\end{array}$ & $\begin{array}{l}\text { Requires } \\
\text { regular } \\
\text { cleaning } \\
\text { Filter } \\
\text { replacement } \\
\text { costs }\end{array}$ & $\begin{array}{l}\text { (Belter et al., } \\
\text { 1988; Bhayani } \\
\text { and Ramarao, } \\
\text { 2013; Brennan } \\
\text { and Owende, } \\
\text { 2010; Molina } \\
\text { Grima et al., } \\
\text { 2003) }\end{array}$ \\
\hline $\begin{array}{l}\text { Membranes } \\
\text { (MF-cell } \\
\text { harvesting/ } \\
\text { removal) }\end{array}$ & $\begin{array}{l}\text { Particle/ } \\
\text { molecular size } \\
\text { Pressure } \\
\text { gradient }\end{array}$ & $\begin{array}{l}\text { Average flux } \\
\text { Energy required } \\
\text { in }(\mathrm{kWh} / \mathrm{m} 3 \\
\text { permeate) }\end{array}$ & $\begin{array}{l}\text { Product } \\
\text { recovery } \\
\text { efficiency } \sim 85 \\
\text { to } 99 \%\end{array}$ & $\begin{array}{l}\text { High } \\
\text { concentration } \\
\text { factor } \\
\text { Moderate to }\end{array}$ & $\begin{array}{l}\text { Membrane } \\
\text { fouling } \\
\text { Replacement } \\
\text { costs }\end{array}$ & $\begin{array}{l}\text { (Ho and Sirkar, } \\
\text { 1992; Jönsson, } \\
\text { 2013; Mänttäri et } \\
\text { al., 2013; van }\end{array}$ \\
\hline
\end{tabular}




\begin{tabular}{|c|c|c|c|c|c|c|}
\hline $\begin{array}{l}\text { (MF,UF, NF, } \\
\text { RO-phase }\end{array}$ & MSA(membrane) & $\begin{array}{l}M F-2, U F-5, R O \\
-9\end{array}$ & & high costs & & $\begin{array}{l}\text { Reis and Zydney, } \\
2007,2001)\end{array}$ \\
\hline 10 & $\begin{array}{l}\text { Hydrophobicity } \\
\text { Size and density } \\
\text { MSA(air) }\end{array}$ & $\begin{array}{l}\text { Air pumping } \\
\text { should lead to } \\
\text { supersaturation } \\
\text { and microbubble } \\
\text { nucleation }\end{array}$ & $\begin{array}{l}\text { Product } \\
\text { recovery } \\
\text { efficiency } \sim 80 \\
\text { to } 90 \%\end{array}$ & $\begin{array}{l}\text { Applicable to } \\
\text { low density, } \\
\text { colloidal size } \\
\text { range particles } \\
\text { Useful when } \\
\text { water is scarce }\end{array}$ & $\begin{array}{l}\text { Energy } \\
\text { intensive } \\
\text { Limited } \\
\text { application } \\
\text { Difficulties in } \\
\text { scale-up }\end{array}$ & $\begin{array}{l}\text { (Brennan and } \\
\text { Owende, 2010; } \\
\text { Hanotu et al., } \\
\text { 2012; Najafpour, } \\
\text { 2015) }\end{array}$ \\
\hline $\begin{array}{l}\text { Ultrasonic } \\
\text { separation }\end{array}$ & $\begin{array}{l}\text { Ultrasonic waves } \\
\text { ESA (radiation } \\
\text { forces) }\end{array}$ & $\begin{array}{l}\text { Optimal } \\
\text { sonication } \\
\text { intensity - } 47.2 \\
W / \mathrm{cm}^{2}\end{array}$ & $\begin{array}{l}\text { Product } \\
\text { recovery } \\
\text { efficiency } \sim 80 \\
\text { to } 92 \%\end{array}$ & $\begin{array}{l}\text { Non-fouling, no } \\
\text { shear, absence } \\
\text { of mechanical } \\
\text { failures } \\
\text { Ability to } \\
\text { operate } \\
\text { continuously } \\
\text { subsection } 4.3 .\end{array}$ & $\begin{array}{l}\text { Energy } \\
\text { intensive } \\
\text { Difficulties in } \\
\text { scale-up }\end{array}$ & $\begin{array}{l}\text { (Bosma et al., } \\
\text { 2003; Coakley et } \\
\text { al., 1994; Show et } \\
\text { al., 2013) }\end{array}$ \\
\hline tion & $\begin{array}{l}\text { Solubility of } \\
\text { product } \\
\text { pH and } \\
\text { temperature } \\
\text { change } \\
\text { MSA (solvent) }\end{array}$ & $\begin{array}{l}\text { Selective } \\
\text { solubility of the } \\
\text { desired product }\end{array}$ & $\begin{array}{l}\text { Depend on } \\
\text { solvent } \\
\text { selectivity }\end{array}$ & $\begin{array}{l}\text { Widely used } \\
\text { for all types of } \\
\text { products } \\
\text { Low utility cost }\end{array}$ & $\begin{array}{l}\text { Solvent costs } \\
\text { and recovery } \\
\text { issues } \\
\text { Higher } \\
\text { downstream } \\
\text { costs }\end{array}$ & $\begin{array}{l}\text { (Choi and Lee, } \\
\text { 1997; Epp and } \\
\text { Fetterolf, 2009; } \\
\text { Singh and Panda, } \\
\text { 2005) }\end{array}$ \\
\hline $\begin{array}{l}\text { Differential } \\
\text { digestion }\end{array}$ & $\begin{array}{l}\text { Solubility of } \\
\text { NPCM } \\
\text { MSA(digestion } \\
\text { agent) }\end{array}$ & $\begin{array}{l}\text { Product must be } \\
\text { intracellular } \\
\text { Selective } \\
\text { solubility of } \\
\text { NPCM }\end{array}$ & $\begin{array}{l}\text { Depend on } \\
\text { agent } \\
\text { availability an } \\
\text { product } \\
\text { stability }\end{array}$ & $\begin{array}{l}\text { Physical } \\
\text { separation } \\
\text { Less } \\
\text { downstream } \\
\text { operations }\end{array}$ & $\begin{array}{l}\text { Recovery of } \\
\text { digestion } \\
\text { agent is not } \\
\text { possible }\end{array}$ & $\begin{array}{l}\text { (Choi and Lee, } \\
\text { 1999; Sayyed et } \\
\text { al., 2009) }\end{array}$ \\
\hline
\end{tabular}

\section{Stage II - Product concentration}

Product is usually present in dilute concentrations in the stream isolated in the first stage. Thus, stage II - product concentration is applied to recover product from dilute streams. The most common technology options in stage II are conventional liquid-liquid extraction, aqueous two phase extraction, evaporation, precipitation, adsorption, distillation, pervaporation for soluble products and high resolution membrane separations such as ultrafiltration, nanofiltration and reverse osmosis, and high speed centrifugation for insoluble products. However, these technologies may be used in combination based on the characteristics of the stream coming from previous stages for efficient product recovery.

\subsection{Liquid-liquid extraction}

Liquid-liquid extraction also known as solvent extraction is used for recovery of products such as alcohols, carboxylic acids, antibiotics, amino acids, proteins, etc. The selection of liquid extractant or solvent is dependent on properties such as selectivity, non-toxicity, cost, immiscibility in water and ease of recovery and recyclability (Koch and Shiveler, 2015). The addition of a relatively immiscible organic solvent to dilute aqueous stream containing the product, results in two phases. The extraction of product from the aqueous phase to the solvent phase is based on its solubility difference in two phases, the extract 
(solvent-rich) and raffinate (water-rich) phase. The ratio of the concentrations of the product in two phases is known as the distribution or partition coefficient $\left(\kappa_{D}\right.$ or $\kappa_{P}$ ) (Towler and Sinnott, 2012). Extraction can be performed in single or multiple stages. Sometimes, multiple components are present in the stream hence the selectivity of the solvent is taken into consideration. The selectivity coefficient $\left(\beta_{a b}\right)$ is the ratio of partition coefficient of component ' $a$ ' to the component ' $b$ '. The higher the value of the selectivity coefficient the easier it is to separate the components. The selectivity can be altered with changes in pH values (Shuler and Kargi, 1992).

\subsection{Aqueous two phase extraction}

Liquid-liquid extraction using an organic solvent is generally not suitable for separation and recovery of biomolecules such as proteins because it can cause denaturation. In such systems, the aqueous two phase extraction (ATPE) has proved to be more efficient, especially in process integration for a continuous operation (Asenjo and Andrews, 2012). ATPE has proved to be a promising technology for separation of biological products such as proteins (Sikdar et al., 1991), genetic material, bionanoparticles, phytochemicals, complete cells or certain cell organelles. The aqueous two phases can be composed of polymers (polyethylene glycol, dextran, polypropylene glycol), salts (phosphates, sulfates), low molecular weight alcohols (ethanol, propanol), surfactants (n-decyl tetraethylene oxide, octylphenol ethoxylate), and ionic liquids (Benavides et al., 2011). These when combined together over critical concentrations result in the formation of two phases. The biomolecules and cell fragments can be partitioned between these two phases. The phases are called top phase and bottom phase and the extent of partitioning depends on the equilibrium relationship for the system. The partition coefficient $\left(\kappa_{P}\right)$ is ratio of the equilibrium concentrations of a component ' $a$ ' in the top phase to that in the bottom phase. If $\kappa_{P}>1$, then the component prefers the top phase and if $\kappa_{P}<1$, then it is concentrated in the bottom phase (Doran, 2012). Partitioning behavior is influenced by the size, electric charge, hydrophobicity and biospecific affinity of the product molecules. Affinity ligands have been used to enhance the selectivity of protein partitioning (HattiKaul, 2001; Walter and Johansson, 1994). These ligands have the ability to bind specifically and reversibly with target protein in one of the phases of the system.

\subsection{Evaporation}

Evaporation is used for concentrating the solution by boiling off the excess solvent, usually water and if performed under low pressure or vacuum it can be operated at low temperatures (range of $40-90^{\circ} \mathrm{C}$ ). Large throughputs can be handled and final solids concentration achieved can be higher as compared to most filtration operations (Freese, 1996). Evaporators can be single or multistage (Seader et al., 2010) based on the capacity desired. Also, the latent heat of the vaporized material can be utilized in multistage system. However, the disadvantage of evaporation is that it can only perform product concentration but no product purification (Grandison and Lewis, 1996). 


\subsection{Precipitation}

Precipitation is used for product concentration and fractionation (Kennedy and Cabral, 1993). Fractionation or selective precipitation of desired components can be enabled by addition of salts, solvents and polymers, or changes in $\mathrm{pH}$, ionic strength and temperature. Precipitation can be a following step to an ATPE separation, for example, some proteins can be precipitated by addition of organic acids, salts and non-ionic polymers (Harrison et al., 2003). Precipitations with solvent addition performed at low temperatures are better for some proteins because they increase recovery and prevent denaturation. Precipitate formation is sensitive to ionic strength of the solution. At higher values more solvent addition is required which results in a fine precipitate and can lead to difficulties in further downstream processing. Products with high molecular weight require less solvent addition. Salts with multiply charged anions such as, sulfate, phosphate and citrate are more effective; while for the case of cations, monovalent ions are better (Scopes, 1994). Precipitations performed by altering conditions, such as temperature and pH, should take care of the possibility of product denaturation in case of exposure to extreme conditions (Belter et al., 1988; Filho et al., 2011). Usually experimental insights are essential to determine the critical parameters for precipitation.

\subsection{Adsorption}

Adsorption of solutes from solutions on surfaces of solid adsorbents is a common method for selectively separating materials based on surface properties. Adsorption can be categorized as physical or chemical based on the forces involved. Solute is transferred from the liquid phase to the solid surface till equilibrium is attained (Shuler and Kargi, 1992). Thus, selecting a suitable adsorbent that can adsorb large amounts of solute molecules is desirable. The most widely used adsorbent is activated carbon, since it has a large internal surface area per unit mass. In adsorption, the important steps are: addition of feed to adsorbent, selective adsorption of solute molecules on the surface of adsorbent, removal of spent feed (free of solutes) solution and elution of adsorbed solute using a different solvent for adsorbent regeneration (Belter et al., 1988; Qureshi et al., 2005; Sun et al., 2011; Venkatesan, 2013). Adsorption is often compared to liquid-liquid extraction; it has a smaller capacity but higher selectivity towards the product and can avoid product denaturation. However, data available on adsorbents is limited and needs experimental insights. Due to their low capacity, high cost and selective nature they are mainly used for specialty products.

\subsection{Distillation}

In distillation, the separation is dependent upon the vapor pressures and boiling points of the substances. The relative volatility of components in a liquid mixture can be computed by using their vapor pressures and is used to determine the ease of separation between the more volatile (lower boiling point) and the less volatile (higher boiling point) components. For complete separation between the components, 
the feed is introduced at an intermediate plate; a bottom product relatively free of the more volatile component and an overhead product relatively free of the less volatile component are obtained in exiting streams from the distillation column (Belter et al., 1988; Diwekar, 2011; Towler and Sinnott, 2012). Distillation usually follows the liquid-liquid extraction technology with the feed being the extract phase and performs product purification and recovery of solvent for recycling. The volatile organic solvents are usually vaporized from the feed and are condensed as the 'distillate' for recycle, while the non-volatile components are recovered in the 'bottoms'. Direct distillation for recovery of bio-based chemicals is often cost intensive because they are present in dilute concentrations in aqueous solutions. The relative volatility of product may not have a reasonable value; distillations are usually avoided if relative volatility is less than 1.05. Also, heat of vaporization of organic solvents used in extraction processes is much lower as compared to water (Seader et al., 2010).

\subsection{Pervaporation}

Pervaporation derives its name from the combination of two operations, the permeation of a permeate through the membrane and its phase change from liquid to vapor while it permeates the membrane barrier (Huang, 1991). The two driving forces for pervaporation are concentration gradient and difference in partial pressure across the membrane. It is used for separation of special type of liquid mixtures. The applications depend upon the two specific properties of the membranes used - hydrophilic and organophilic. They can be used for removal of small amounts of volatile organic compounds, solvent dehydration and separation of organic mixtures (Mulder et al., 1983; Valentínyi et al., 2013). Pervaporation is environment friendly because of the low energy requirements and the absence of any added components during the operation. It can be used after distillation for further refinement of the product and remove any traces of water or other volatile organic compounds (Sikdar et al., 2001).

\subsection{Summary of technologies in stage II - Product concentration}

The technologies available in stage II are summarized in Table 6.

Table 6 Summary of technologies in stage II - Product concentration

\begin{tabular}{|c|c|c|c|c|c|c|}
\hline Technology & $\begin{array}{l}\text { Principle/ } \\
\text { Driving force }\end{array}$ & $\begin{array}{l}\text { Important } \\
\text { Conditions }\end{array}$ & $\begin{array}{l}\text { Performance } \\
\text { parameters }\end{array}$ & Advantages & Drawbacks & References \\
\hline $\begin{array}{l}\text { Liquid-liquid } \\
\text { extraction }\end{array}$ & $\begin{array}{l}\text { Solubility } \\
\text { Partition } \\
\text { coefficient } \\
\text { MSA(solvent) }\end{array}$ & $\begin{array}{l}\text { Selectivity, } \\
\beta>1 \\
\text { Low solubility } \\
\text { of solvent in } \\
\text { water }\end{array}$ & $\begin{array}{l}\text { Product } \\
\text { recovery } 70 \\
\text { to } 96 \%\end{array}$ & $\begin{array}{l}\text { Can handle } \\
\text { dilute } \\
\text { concentrations } \\
\text { Low energy } \\
\text { requirement }\end{array}$ & $\begin{array}{l}\text { Solvent cost } \\
\text { and } \\
\text { recyclability }\end{array}$ & $\begin{array}{l}\text { (Backhaus et al., } \\
\text { 2015; Birajdar et } \\
\text { al., 2014; Seader } \\
\text { et al., 2010; } \\
\text { Shuler and Kargi, } \\
\text { 1992; Towler and } \\
\text { Sinnott, 2012) }\end{array}$ \\
\hline ATPE & $\begin{array}{l}\text { Biospecific } \\
\text { affinity } \\
\text { MSA(polymer, } \\
\text { salts, alcohols) }\end{array}$ & $\begin{array}{l}\text { High MW } \\
\text { polymer } \\
\text { Two phase } \\
\text { composition }\end{array}$ & $\begin{array}{l}\text { Product } \\
\text { recovery } 76 \\
\text { to } 94 \%\end{array}$ & $\begin{array}{l}\text { Larger density } \\
\text { gradients } \\
\text { Non-toxic } \\
\text { Biodegradable }\end{array}$ & $\begin{array}{l}\text { Cost of } \\
\text { polymer } \\
\text { Recovery and } \\
\text { recycling of }\end{array}$ & $\begin{array}{l}\text { (Asenjo and } \\
\text { Andrews, 2012; } \\
\text { Backhaus et al., } \\
\text { 2015; Benavides }\end{array}$ \\
\hline
\end{tabular}




\begin{tabular}{|c|c|c|c|c|c|c|}
\hline & & & & & $\begin{array}{l}\text { two phase } \\
\text { components }\end{array}$ & $\begin{array}{l}\text { et al., 2011; } \\
\text { Doran, 2012) }\end{array}$ \\
\hline Evaporation & $\begin{array}{l}\text { Vapor pressure } \\
\text { Boiling point } \\
\text { ESA(heat) }\end{array}$ & $\begin{array}{l}\text { High } \\
\text { temperature or } \\
\text { vacuum } \\
\text { Energy } \\
\text { required per kg } \\
\text { evaporated } \\
\sim 1.2 \mathrm{~kg} \text { steam } \\
0.04 \mathrm{kWh}\end{array}$ & $\begin{array}{l}\text { Product } \\
\text { concentration } \\
\sim 95 \text { to } 99 \%\end{array}$ & $\begin{array}{l}\text { High product } \\
\text { concentration } \\
\text { Widely used in } \\
\text { industries }\end{array}$ & $\begin{array}{l}\text { High costs } \\
\text { No impurity } \\
\text { removal }\end{array}$ & $\begin{array}{l}\text { (Freese, 1996; } \\
\text { Grandison and } \\
\text { Lewis, 1996; } \\
\text { Seader et al., } \\
\text { 2010) }\end{array}$ \\
\hline Precipitation & $\begin{array}{l}\text { Ionic charges } \\
\text { Solubility } \\
\text { MSA } \\
\text { (antisolvent) }\end{array}$ & $\begin{array}{l}\text { Amount of } \\
\text { antisolvent } \\
\text { Temperature or } \\
\text { pH change }\end{array}$ & $\begin{array}{l}\text { Product } \\
\text { recovery } 60 \\
\text { to } 90 \%\end{array}$ & $\begin{array}{l}\text { Low cost } \\
\text { No product } \\
\text { degradation }\end{array}$ & $\begin{array}{l}\text { Difficulties in } \\
\text { control and } \\
\text { scale-up }\end{array}$ & $\begin{array}{l}\text { (Belter et al., } \\
\text { 1988; Filho et al., } \\
\text { 2011; Harrison et } \\
\text { al., 2003; Jeon et } \\
\text { al., 2014) }\end{array}$ \\
\hline Adsorption & $\begin{array}{l}\text { Surface forces } \\
\text { MSA } \\
\text { (adsorbent) }\end{array}$ & $\begin{array}{l}\text { High surface } \\
\text { area to volume } \\
\text { ratio for } \\
\text { adsorbent }\end{array}$ & $\begin{array}{l}\text { Product } \\
\text { recovery } 70 \\
\text { to } 95 \%\end{array}$ & $\begin{array}{l}\text { Higher } \\
\text { selectivity }\end{array}$ & $\begin{array}{l}\text { Low capacity } \\
\text { Difficulties in } \\
\text { scale-up }\end{array}$ & $\begin{array}{l}\text { (Belter et al., } \\
\text { 1988; Qureshi et } \\
\text { al., 2005; Sun et } \\
\text { al., 2011) }\end{array}$ \\
\hline Distillation & $\begin{array}{l}\text { Vapor pressure } \\
\text { Relative } \\
\text { volatility } \\
\text { ESA(heat, } \\
\text { pressure) }\end{array}$ & $\begin{array}{l}\text { Relative } \\
\text { volatility }>1.05 \\
\text { Energy } \\
\text { required in } \mathrm{kg} \\
\text { steam } / \mathrm{kg} \\
\text { evaporated } \\
\sim 1.3 \times \Delta H_{\text {vap }}\end{array}$ & $\begin{array}{l}\text { Product } \\
\text { recovery } ~ 80 \\
\text { to } 99 \%\end{array}$ & $\begin{array}{l}\text { Higher purity } \\
\text { Widely used in } \\
\text { industries }\end{array}$ & $\begin{array}{l}\text { Energy } \\
\text { intensive } \\
\text { High } \\
\text { operating cost }\end{array}$ & $\begin{array}{l}\text { (Diwekar, 2011; } \\
\text { Gorak and } \\
\text { Sorensen, 2014; } \\
\text { Lei and Chen, } \\
\text { 2013; Seader et } \\
\text { al., 2010; Towler } \\
\text { and Sinnott, } \\
\text { 2012) }\end{array}$ \\
\hline Pervaporation & $\begin{array}{l}\text { Concentration } \\
\text { and partial } \\
\text { pressure } \\
\text { gradient } \\
\text { MSA } \\
\text { (membrane) } \\
\text { ESA(heat) }\end{array}$ & $\begin{array}{l}\text { Temperature } \\
\text { and pressure } \\
\text { depend on the } \\
\text { components } \\
\text { involved } \\
\text { Membrane pore } \\
\text { size }\end{array}$ & $\begin{array}{l}\text { Product } \\
\text { recovery } \\
\sim 90 \text { to } 99 \%\end{array}$ & $\begin{array}{l}\text { Independent of } \\
\text { VLE conditions } \\
\text { Environment } \\
\text { friendly }\end{array}$ & $\begin{array}{l}\text { Membrane } \\
\text { fouling and } \\
\text { replacement } \\
\text { costs } \\
\text { Not used at } \\
\text { industrial } \\
\text { scale }\end{array}$ & $\begin{array}{l}\text { (Feng and Huang, } \\
\text { 1997; Huang, } \\
\text { 1991; Mulder et } \\
\text { al., 1983; Shao } \\
\text { and Kumar, 2009; } \\
\text { Sikdar et al., } \\
\text { 2001) }\end{array}$ \\
\hline $\begin{array}{l}\text { Membranes } \\
(\mathrm{MF}, \mathrm{UF}, \mathrm{NF}, \mathrm{RO})\end{array}$ & \multicolumn{6}{|c|}{ refer to Table 5 in subsection 4.5} \\
\hline
\end{tabular}

\section{Stage III - Product purification and refinement}

Stage III is dependent upon the physical state of the product, its intended application and final purity. The products for industrial purposes (commodity chemicals) can be of lower purity grade when compared to products for pharmaceutical applications (specialty or fine chemicals). Thus, in some cases stage-III may not be required since desired purity would have been achieved in the previous stages. During purification and refinement, the major impurities left are traces of co-products with similar properties to the product, solvents and color imparting materials. The colored materials can be removed by bleaching while pervaporation, drying, crystallization and chromatography are useful for removing organic solvents, water and co-products.

\subsection{Crystallization}


Crystallization is widely used in chemical and pharmaceutical industries for preparation of solid crystalline products with desired attributes such as their shape, size and purity. Many commodity chemicals and organic fine chemicals are marketed as crystalline products. The important characteristics of crystalline products are that they are usually of high purity, they can be easily isolated from the bulk solution in the subsequent steps such as filtration and drying and their overall appearance is enhanced due to the crystalline structure (Belter et al., 1988). Crystallization is influenced by solid-liquid equilibrium between the solute and solvent; the solute will not crystallize unless the solution is supersaturated. Supersaturation is a condition where the solute concentration in the solution is higher than its solubility. This concentration gradient is the major driving force for crystallization (Harrison et al., 2003; Hill, 2005). Crystallization kinetics involves two major phenomena; (i) nucleation or formation of new crystals and (ii) growth by deposition of solute molecules on surface of existing crystals. Solubility is a temperature dependent property and it decreases with the decrease in temperature for majority of products. Most crystallizations are performed by heating the solution to a high temperature and then cooling it gradually for the formation of crystals, this is called 'cooling crystallization'. Sometimes, crystallization is carried out by vaporizing the excess solvent from the solution, thus maintaining the supersaturation level for crystal formation at a relatively constant temperature, this is called 'evaporative crystallization'.

\subsection{Drying}

Drying is used for removal of solvent from the purified wet product, usually in the form of dissolved solute or crystals. While selecting the drying operation, the physical properties of the product, its thermal sensitivity, and desired final composition must be taken into consideration. The important parameters in drying operation are; initial water/solvent content of the product, rate at which the water/solvent will evaporate and product susceptibility to degradation at the operating conditions of the dryer (Belter et al., 1988).

Different types of dryers can be used for bio-based chemicals based on their operating conditions and drying efficiency (Harrison et al., 2003; Shuler and Kargi, 1992). Vacuum tray dryer is used for pharmaceutical grade products and consists of heated shelves in a single chamber. It is operated as a batch process and is used for expensive products so that product loss and damage can be minimized. In freeze drying (lyophilization) (Pisano et al., 2013) water or solvents are removed by sublimation from the frozen solution. For freezing the material before drying, usually a vacuum chamber is used. This method is particularly used for sensitive products such as antibiotics, enzymes and bacterial suspensions. In rotary drum dryers (Pacheco and Stella, 1998) water is removed by conduction of heat over a thin film of solution on a steam heated surface. This is carried out in an inclined rotating drum and the dried product sticks to the drum surface, which is recovered at the discharge point. This is not suitable for crystalline products. In spray dryers, the product solution is atomized and sprayed into a heated chamber through a 
nozzle. The hot gases in the heated chamber evaporate excess solvent in the product. The dried particles in the gaseous stream are then separated using a cyclone separator. The capital cost for spray drying is high, but it is preferred for heat sensitive materials. In pneumatic conveyor dryers the materials to be dried are suspended in a hot stream of air. The air flow is maintained such that particles have a low retention time in the stream, usually in the order of seconds. These are useful when surface drying is important, cannot be used for porous materials

\subsection{Chromatography}

Chromatography is used for separation of liquid mixtures into its components by passing it through a bed of adsorbent material. Different solutes present in the mixture interact differently with the adsorbent; some have strong interaction while some interact weakly. This difference in their interaction affects their residence time in the chromatography column and results in differential recovery of individual components. There are different types of chromatographic methods (Shuler and Kargi, 1992; Sun et al., 2011) such as adsorption chromatography wherein the solute molecules are adsorbed on the surface of the adsorbent material, usually alumina or silica gel, by weak van der Waals forces and steric attraction. Liquid-liquid partition chromatography is based on the difference in solubility of the solute molecules in the adsorbed liquid phase and the passing solution. In ion-exchange chromatography the electrically charged molecules or ions are adsorbed on the surface of ion-exchange resins due to electrostatic forces of attraction. Gel-filtration or size exclusion chromatography is based on the penetration of desired solute molecules into the pores of packing material. Its efficiency is a function of the difference in molecular size and shape of solute molecules as compared to other molecules present in the liquid mixture. In affinity chromatography specific ligand molecules are used which have the ability to interact with the solute molecules and form bonds. These ligand-solute interactions are very specific and can depend upon the formation of covalent, ionic or hydrogen bonds. It may depend on the molecular size and shape of the solute. Hydrophobic chromatography is based on the hydrophobic interactions between the solute molecules and other functional groups on the surface of the adsorbent material. In high-pressure liquid chromatography, pressurized liquid stream flows into the packed columns, while other conditions are the same as in any typical chromatographic technology. The pressurized liquid flow and the dense column packing result in fast isolation and high resolution of solute molecules. Sometimes, a combination of two or more chromatographic methods having different driving forces can result in better product refinement (Dyson, 1998; Garcia and Pires, 1993; Özdural, 2011).

\subsection{Bleaching}

Bleaching or decolorization is performed for the removal of color imparting impurities to enhance the appearance of the product. Often products, such as oils and lipids (List, 2009) extracted from microbial processes, can have traces of colored pigments, such as chlorophyll, carotenoids and xanthophyll. If these 
pigments get oxidized they can generate darker colors affecting the overall appearance as well as product acceptability in the market (Varzakas and Tzia, 2015). Bleaching operation can also remove some residual soaps (alkalis), trace metals and oxidized impurities. It usually involves the use of an adsorbent such as activated carbon which can adsorb all the color imparting impurities and subsequent filtration or membrane processes depending upon the size of the adsorbent and impurities involved (Brooks et al., 2015; Ramli et al., 2011). Bleaching is actually a special type of adsorption that may involve multiple physical and chemical reactions which are affected by process variables such as moisture content, temperature, contact time, material handled in the process and adsorbent properties. The bleaching efficiency depends on removal of potential contaminants that can affect bleaching in the previous tasks. Hence, it is usually one of the last technologies in the overall separation configuration.

\subsection{Summary of technologies in stage III - Product purification and refinement}

Stage III is required to obtain the desired purity of the product and for polishing it to the marketable form. The technologies in this stage are summarized in Table 7. Depending upon the final product quality and its end use, a combination of technologies can be used.

Table 7 Summary of technologies in stage III - Product purification and refinement

\begin{tabular}{|c|c|c|c|c|c|c|}
\hline Technology & $\begin{array}{l}\text { Principle/ } \\
\text { Driving force }\end{array}$ & $\begin{array}{l}\text { Important } \\
\text { conditions }\end{array}$ & $\begin{array}{l}\text { Performance } \\
\text { parameters }\end{array}$ & Advantages & Drawbacks & References \\
\hline Crystallization & $\begin{array}{l}\text { Concentration } \\
\text { gradient } \\
\text { ESA (cooling } \\
\text { or heating } \\
\text { utility) }\end{array}$ & $\begin{array}{l}\text { Supersaturation } \\
\text { maintenance by } \\
\text { cooling or } \\
\text { evaporation } \\
\text { Efficient mixing }\end{array}$ & $\begin{array}{l}\text { Product } \\
\text { purity } 90 \text { to } \\
96 \%\end{array}$ & $\begin{array}{l}\text { Product } \\
\text { homogeneity } \\
\text { Enhanced } \\
\text { appearance and } \\
\text { purity }\end{array}$ & $\begin{array}{l}\text { Requires } \\
\text { pure input } \\
\text { with no solid } \\
\text { contaminants } \\
\text { High costs }\end{array}$ & $\begin{array}{l}\text { (Belter et al., } \\
\text { 1988; Filho et } \\
\text { al., 2011; } \\
\text { Glasgow, } \\
\text { 2014; } \\
\text { Harrison et al., } \\
\text { 2003; Hill, } \\
2005 \text { ) }\end{array}$ \\
\hline Drying & $\begin{array}{l}\text { Temperature } \\
\text { Vapor } \\
\text { pressure } \\
\text { ESA(heating } \\
\text { or cooling) }\end{array}$ & $\begin{array}{l}\text { Different types } \\
\text { can be used } \\
\text { based on } \\
\text { product thermal } \\
\text { sensitivity }\end{array}$ & $\begin{array}{l}\text { Product } \\
\text { purity } \sim 90 \text { to } \\
98 \%\end{array}$ & $\begin{array}{l}\text { Easier product } \\
\text { handling } \\
\text { Widely used } \\
\text { Easy to scale-up }\end{array}$ & $\begin{array}{l}\text { Energy } \\
\text { intensive } \\
\text { High capital } \\
\text { and } \\
\text { operating } \\
\text { costs }\end{array}$ & $\begin{array}{l}\text { (Backhaus et } \\
\text { al., 2015; } \\
\text { Harrison et al., } \\
\text { 2003; Shuler } \\
\text { and Kargi, } \\
\text { 1992) }\end{array}$ \\
\hline Chromatography & $\begin{array}{l}\text { Surface charge } \\
\text { Molecular size } \\
\text { Shape } \\
\text { MSA (resins, } \\
\text { charged } \\
\text { molecules) }\end{array}$ & $\begin{array}{l}\text { Depend upon } \\
\text { product } \\
\text { properties and } \\
\text { type of } \\
\text { chromatography }\end{array}$ & $\begin{array}{l}\text { Product } \\
\text { purity 80 to } \\
99 \%\end{array}$ & $\begin{array}{l}\text { Can combine } \\
\text { chromatography } \\
\text { methods } \\
\text { Widely used for } \\
\text { specialty } \\
\text { products }\end{array}$ & $\begin{array}{l}\text { High cost } \\
\text { Difficulties in } \\
\text { scale-up } \\
\text { Product } \\
\text { dilution }\end{array}$ & $\begin{array}{l}\text { (Backhaus et } \\
\text { al., 2015; } \\
\text { Garcia and } \\
\text { Pires, 1993; } \\
\text { Shuler and } \\
\text { Kargi, 1992; } \\
\text { Sun et al., } \\
\text { 2011) }\end{array}$ \\
\hline Bleaching & $\begin{array}{l}\text { Surface charge } \\
\text { MSA(bleaching } \\
\text { agent) }\end{array}$ & $\begin{array}{l}\text { Usually last } \\
\text { operation to } \\
\text { remove color }\end{array}$ & $\begin{array}{l}\text { Product } \\
\text { purity } \\
\sim 90 \text { to } 99 \%\end{array}$ & $\begin{array}{l}\text { Enhancement of } \\
\text { product purity } \\
\text { and appearance }\end{array}$ & $\begin{array}{l}\text { Depends on } \\
\text { efficiency of } \\
\text { previous }\end{array}$ & $\begin{array}{l}\text { (Brooks et al., } \\
\text { 2015; List, } \\
\text { 2009; Ramli et }\end{array}$ \\
\hline
\end{tabular}




\begin{tabular}{|c|c|c|c|}
\hline & $\begin{array}{l}\text { imparting } \\
\text { impurities, } \\
\text { Temperature } \\
\text { and adsorbent } \\
\text { capacity }\end{array}$ & $\begin{array}{l}\text { Can be scaled- operations } \\
\text { up }\end{array}$ & $\begin{array}{l}\text { al., 2011; } \\
\text { Varzakas and } \\
\text { Tzia, 2015) }\end{array}$ \\
\hline Pervaporation & \multicolumn{2}{|c|}{ refer to Table 6 in subsection 5.8} & \\
\hline
\end{tabular}




\section{Separation schemes}

One of the major goals in the design of a large scale commercial process is the minimization of processing cost while maintaining product specifications. In the production of biochemicals, downstream separation is the major cost driver (Brandt and Schembecker, 2016; Kiss et al., 2015; Shaeiwitz et al., 2000). Hence, systematic methods for the synthesis of separation networks are required (Barnicki and Siirola, 2004; Yeomans and Grossmann, 1999). A separation scheme (Pavia, 2005) starts with the effluent of a (bio)reactor and is a systematic representation of the options for product isolation from a mixture of components. In this work, we build separation schemes showing the recovery and purification of the product of interest from a mixture of components present in the stream leaving the cultivation bioreactor. The information essential for the generation of these schemes (Asenjo and Andrews, 2008) is listed below:

1) Characterization of starting materials (discussed in subsection 2.3),

2) Specification of desired product purity and intended use

3) Technologies available for different separation tasks, their driving forces, important operating conditions, efficiency, cost and scalability (discussed in sections 4, 5 and 6)

Based on information from (1) and (2), we define the active separation stages and tasks for a particular chemical. Based on (3) we list the potential technology alternatives capable of performing the intended tasks. Thus, we will be able to generate a separation scheme for a bio-based chemical which shall be inclusive of appropriate technology options. This scheme will act as a building block for the synthesis of the optimal separation network. In the following subsections we present guidelines for selection of technologies while generating a separation scheme.

\subsection{Identification of technologies based on product characteristics}

Separation technologies exploit one or more properties of the product. The higher the property difference between the product and other components in the system, the better is the separation. Table 8 lists the potential product properties and choice of separation alternatives corresponding to each property (Atkinson and Mavituna, 1991; Ghosh, 2006; Shuler and Kargi, 1992; Singh and Singh, 1996).

Table 8 Selection of separation technologies based on product properties

\begin{tabular}{ll}
\hline Property & Separation technologies \\
\hline Size & Filtration, membrane processes, centrifugation \\
Density & Centrifugation, sedimentation, flotation \\
Diffusivity & Dialysis, reverse osmosis, pervaporation \\
Shape & Centrifugation, sedimentation, filtration \\
Polarity & ATPE, extraction, chromatography, adsorption \\
Solubility & Extraction, crystallization, precipitation \\
Electrostatic charge & Adsorption, membrane processes, flotation \\
Volatility & Distillation, pervaporation \\
Vapor pressure & Distillation, drying \\
\hline
\end{tabular}


In addition to product properties, another important aspect in selection of separation technology is the physical state of components in the process stream and desired state after separations. Table 9 provides some guidelines for selection of separation technologies based on physical state of components and phase changes.

Table 9 Selection of separation technologies based on physical state of components and phase changes*

\begin{tabular}{llll}
\hline System & Type & Phase change & No phase change \\
\hline \multirow{2}{*}{ Solid-liquid } & Soluble/Miscible & $\begin{array}{l}\text { Drying, crystallization, } \\
\text { evaporation, adsorption }\end{array}$ & Ultrafiltration, reverse osmosis \\
& Insoluble/Immiscible & Drying & $\begin{array}{l}\text { Filtration, sedimentation, } \\
\text { centrifugation }\end{array}$ \\
\cline { 2 - 4 } Liquid-liquid & $\begin{array}{l}\text { Soluble/Miscible } \\
\text { Insoluble/Immiscible }\end{array}$ & $\begin{array}{l}\text { Distillation, extraction } \\
\text { N/A }\end{array}$ & $\begin{array}{l}\text { Chromatography } \\
\text { Sedimentation, centrifugation }\end{array}$ \\
\cline { 2 - 4 } Solid-solid & Soluble/Miscible & Cell disruption methods & N/A \\
& Insoluble/Immiscible & Selective solubilization & $\begin{array}{l}\text { Air aspiration, sieving, screening, } \\
\text { winnowing }\end{array}$ \\
\cline { 2 - 4 } $\begin{array}{l}\text { Liquid-liquid- } \\
\text { solid }\end{array}$ & $\begin{array}{l}\text { Soluble/Miscible } \\
\text { Insoluble/Immiscible }\end{array}$ & $\begin{array}{l}\text { Adsorption } \\
\text { N/A }\end{array}$ & $\begin{array}{l}\text { N/A } \\
\text { Sedimentation, centrifugation, } \\
\text { decanting }\end{array}$ \\
\hline
\end{tabular}

*adapted from (Rao, 2010)

\subsection{Identification of technologies based on product localization}

\subsubsection{Intracellular/non-secreted products}

In case of intracellular products, stage I (cell and product isolation) includes the tasks of pretreatment (optional), cell harvesting, cell disruption and phase isolation. The technology selection for cell harvesting and cell disruption is dependent on the efficiency as well as the operating conditions, since intracellular products are more susceptible to degradation when exposed to harsh temperature and pressure conditions or shear. After cell disruption, product and other cellular components are present in the output stream. The phase isolation task takes care of removal of cell debris and other solid insoluble impurities. Stage II (product concentration) technologies are dependent upon cell constituents such as possible co-products and impurities which are significantly higher in number as compared to extracellular products (discussed in subsection 2.3 and 3.1). If intracellular products are high value, then stage III (product purification and refinement) technologies have to be more effective to meet the purity specifications.

\subsubsection{Extracellular/secreted products}

For extracellular products, the foremost separation task is to remove biomass/cells from the aqueous stream. The cell disruption task is not required. Thus, stage I (cell and product isolation) includes the tasks of pretreatment (optional), cell removal and phase isolation. Stage II (product concentration) is dependent upon the product content in the stream and can involve multiple steps based on recovery 
constraints. Stage III (product purification and refinement) is dependent upon product purity and physical state. The number of co-products and impurities encountered while handling extracellular products is relatively low in comparison to intracellular products.

\subsection{Categorization of separation schemes}

Based on product localization and water solubility (some examples provided in section 2, Tables 1 and 2), the separation schemes can be broadly divided into four distinct categories;

1) Intracellular and insoluble product

2) Intracellular and soluble product

3) Extracellular and insoluble product

4) Extracellular and soluble product

The product localization provides information regarding the essential separation tasks while water solubility indicates the difficulty of separation as water is the major component in the streams. The relevant technologies in stage II and III vary significantly for soluble and insoluble products. Initial technology screening in these four categories is advantageous because most technologies involve nonsharp separations and can result into a very large search space (Steffens et al., 2000). In the following subsections, we present the schemes for the four categories along with some guidelines in terms of technology suitability (fair, good and excellent), conditions applicable $(\diamond)$ and physical state of the final product (solid (S) and liquid (L)). These guidelines are for a generic product belonging to these categories and are provided based on the technology review (section 4, 5 and 6) and the ranking information provided in the supplementary information. Sometimes, case-specific (subsection 3.1) considerations might alter the list of options as well as their suitability grades.

\subsubsection{Intracellular and insoluble product}

The process stream in case of intracellular (IN) and insoluble (NSL) product (Figure 5) contains cells in an aqueous medium. In stage I the process stream may require pretreatment by flocculation or coagulation to increase the effective particle size (flocs of cells) for efficient cell harvesting. Filtration and centrifugation are excellent choices for cell harvesting, followed by sedimentation (requires large area hence increased equipment cost) and microfiltration (membrane fouling and high replacement costs), while flotation is applicable when cells are hydrophobic and in colloidal size range (limited application). Ultrasonic waves are not suitable for large scale cell harvesting applications (high energy consumption and low concentration factors). Water recovered during cell harvesting can be recycled to the microbial

cultivation systems. Cell harvesting is followed by cell disruption to release the product and other cellular constituents in the output stream. In cell disruption, bead mill, chemical lysis (provided that the added chemical does not react with the product) and enzyme lysis (enzyme availability and selectivity towards the product) are preferred options followed by HPH - high pressure homogenization (provided that the 
product remains stable under pressurized condition and relatively dilute stream enters HPH). Phase isolation separates other solid constituents, especially the cell debris from the product using technologies such as solubilization (dissolving the product in a selective solvent) and differential digestion (isolating product by dissolving NPCM in an agent) and then separating the components by similar technologies used in cell harvesting since cell debris and cells have similar physical properties. However, the technology suitability for phase isolation after disruption changes as the particle or molecular size of the intracellular components are smaller than the cells. Thus, sedimentation will not be effective whereas microfiltration and other high resolution membrane processes (UF and RO) may prove suitable since they are available in different pore sizes and have high performance parameters for small size particles. The number of coproducts and impurities can be higher in intracellular products and hence a combination of technologies may be required in stage II and stage III to achieve desired product quality. High speed centrifugation and membranes (MF, UF, NF and RO) can be used for all IN-NSL products, whereas adsorption and precipitation can be used if the product has been solubilized during phase isolation in stage I. Traces of color imparting impurities such as chlorophyll and carotenoids are present in intracellular products and bleaching is often preferred to remove them for product appearance enhancement. Chromatography is a high cost refining technology for specialty products and results in relatively dilute product concentrations, hence is not preferred for chemicals for commercial applications. Drying is a promising technology for solid state products since it removes the remaining water or solvents from the product for easier handling and packaging.

\subsubsection{Intracellular and soluble product}

For intracellular (IN) and soluble (SOL) product (Figure 6), the technology options in stage I are the same as discussed for IN-NSL product in subsection 7.3.1. The suitability grades for pretreatment and cell harvesting technologies are the same while there are some variations for cell disruption and phase isolation options. HPH (high pressure homogenization) could be a good choice as it has been used previously for IN-SOL products (Balasundaram et al., 2011). Soluble products are more susceptible to chemical interactions by acids and alkalis, hence chemical lysis may not be suitable in many cases. Differential digestion is not applicable for phase isolation in case of IN-SOL products because cell debris and most impurities are usually insoluble-solids and can be removed by using membranes, high speed centrifugation or filtration. Cell debris removal must be performed with precision as some technologies in the following stages such as adsorption, chromatography, and crystallization are sensitive to solid state impurities. The adsorbent capacity will reduce due to solid impurity deposits in adsorption sites. Chromatography performance will be affected and faster regeneration cycles would be required. Solid impurities will act as nucleation sites in crystallization and will impair the desired crystal structure. Soluble impurities are taken care of in stage-II mostly by technologies such as extraction, ATPE, distillation and membranes. If the product is desired in solid state then precipitation is another favored option (provided a 
suitable anti-solvent is available) due to low capital and operating costs in comparison to membranes and centrifuge; however, it has some control issues at large scale. Pervaporation is another technology that can be used for soluble products and can be implemented in stage II (as an alternate to distillation or extraction) or stage III (further product purification) depending upon the product and stream characteristics. Furthermore, along with the technologies mentioned in stage III for IN-NSL products (subsection 7.3.1), pervaporation (liquids) and crystallization (solids) can be used for soluble products.

\subsubsection{Extracellular and insoluble product}

In case of extracellular (EX) and insoluble (NSL) products (Figure 7) the tasks in stage I are pretreatment (optional), biomass/cell removal and phase isolation, while cell disruption is not applicable. Cell removal and phase isolation can be performed by using technologies similar to the ones discussed for cell harvesting in subsection 7.3.1. Additionally, solubilization can be used for isolating the product phase from other components by selectively dissolving it in a solvent. This technology is particularly relevant for colloidal size insoluble products which have a tendency to form stable emulsions. In stage II, membranes (MF, UF, NF and RO) are preferable (higher product concentration in output stream), followed by high speed centrifugation (lower product concentration). Precipitation or adsorption can be performed if the product has been solubilized earlier. In stage III, drying is the preferred option for solid state products. Bleaching removes color imparting impurities but the input stream should be relatively pure (free of major impurities) as this is more of an appearance enhancement technology. Chromatography is applicable to products in liquid state and due to high cost and product dilution it is suitable for high value chemicals for specialty applications.

\subsubsection{Extracellular and soluble product}

Biomass or cell removal also applies to extracellular (EX) and soluble (SOL) products (Figure 8), hence stage I is similar to EX-NSL products. However, the difficulty in this case is the uniformly distributed product in the process stream. Thus, stage II can be the most cost-intensive stage involving multiple technologies in series. Product concentration options are usually large scale and comprise two or more technology options where the removal of excess water is followed by product recovery from the added concentrating agent. For example, if extraction is used as the initial product concentration technology, it is followed by distillation to recover the product and solvent from the extract stream at different ends of the distillation column based on relative volatility and boiling point. Technologies such as extraction (provided that the solvent selectivity $>1$ for the product), distillation (requires relative volatility $>1.05$ ), precipitation (solid product and availability of anti-solvent), membranes and pervaporation are preferable options in stage II. ATPE is preferred for sensitive products with bio-specific affinity. In stage III, crystallization, drying and pervaporation are preferred over bleaching and chromatography for commodity chemicals because of the ease of scalability and lower costs of former technology options. However, chromatography 
is still an important purification technology for isolation of soluble products with specialty applications where cost may not be a major concern.

\subsection{Simplification of separation schemes}

Separation schemes discussed in the previous subsection can be further simplified depending on other distinguishing product properties such as its physical state (solid (SLD) or liquid (LQD)), density with respect to water (heavy (HV) or light (LT)) for insoluble products, relative volatility with respect to water (volatile (VOL) and non-volatile (NVL)) for soluble products and intended use (commodity (CMD) or specialty (SPC)), as shown in Figure 9. Some examples are shown for specific product classes such as cyanophycin (Mooibroek et al., 2007), polyhydroxyalkanoates (Choi and Lee, 1997), lipids (Antoni et al., 2007), pigments (Pulz and Gross, 2004), microalgal proteins (Draaisma et al., 2013), $\beta$-phycoerythrin (Kathiresan et al., 2007; Ruiz-Ruiz et al., 2013), hyaluronic acid (Liu et al., 2011), hydrophobic proteins (Chai et al., 2013), itaconic acid (Kuenz et al., 2012; Willke and Vorlop, 2001), glycerol (Wang et al., 2001) and butanediol (Afschar et al., 1993; Anvari et al., 2009).

To illustrate, we present a separation scheme for the product class intracellular-insoluble-solidheavy-commodity (IN-NSL-SLD-HV-CMD) in Figure 10. In this scheme, we have narrowed down the potential technology options for different tasks in each stage based on the characteristics of the entering stream, product properties, possible co-products and impurities, and final product specifications in terms of purity, physical state and appearance. Since, the product is intracellular and insoluble, the differential digestion technology (specific for this class) appears in stage I for phase isolation. Also, the selection of precipitation in stage-II is a case-specific consideration. If the product is solubilized in a selective solvent in stage-I, then it can be recovered in the solid form (desired state) by precipitation. The membrane technology of microfiltration follows precipitation to segregate the solid precipitate and solvent. These case-specific selections are often based on heuristic rules (subsection 3.2) and engineering judgement. Hence, this example should be considered as a demonstration of the proposed ideas and not as a necessarily general scheme for all IN-NSL-SLD-HV-CMD chemicals.

A simplified scheme enables the generation of a separation superstructure (Kokossis et al., 2015; Wu et al., 2016; Yeomans and Grossmann, 1999), which can be used for the systematic synthesis of chemical processes. An example of superstructure development, optimization problem formulation, as well as sample results are presented in the supplementary information to demonstrate the utility of these separation schemes.

\section{Summary}

We presented a roadmap for the synthesis of separation networks based on the properties and

localization of the bio-based chemical as well as the characteristics of the stream entering the downstream 
separation network. Upstream processing (biological) factors such as production route (phototrophic or heterotrophic), microbial strain, substrate and nutrient requirements, bioreactor design, product localization and titer help in narrowing down the list of separation technologies suitable for downstream processing. Separation schemes are generated using information from upstream processing, driving forces, performance parameters, separation technology rankings and final product specifications. These schemes can be used for process evaluation using rigorous modeling and optimization methods, thereby establishing a framework that accounts for both biological and process feasibility. A schematic of the proposed roadmap is shown in Figure 11.

We proposed that downstream separation networks can consist of three stages: (I) cell and product isolation, (II) product concentration and (III) product purification and refinement. Every stage consists of multiple technology alternatives. We presented a comprehensive review of all these technologies along with the details regarding their driving forces, important operating conditions, advantages and drawbacks. Furthermore, we proposed four categories of separation schemes based on product localization and its solubility in water. The physical property differences between the product and other constituents in the process stream act as separation driving forces and they lead to schemes for different product classes. Multiple technology options in every stage and numerous components involved in the process streams can make the technology selection for optimal product recovery highly challenging. Hence, a systematic method for generating simplified separation schemes was demonstrated through an example. A simplified separation scheme enables the generation of a superstructure, which in turn can be used for the formulation of an optimization model for process synthesis and analysis. We believe that the development of schemes in accordance with the proposed stage-wise framework and the simplifications for a specific product class will aid in developing more effective downstream processes. This shall reduce the number of technologies to be evaluated while generating the optimal separation networks. Importantly, it will aid the assessment of conversion technologies for the production of biomass-derived chemicals.

\section{Acknowledgements}

This work was funded by National Science Foundation through the Emerging Frontiers in Research and Innovation program (EFRI-1240268).

\section{References}

Afonso, C.A.M., Crespo, J.P.G., 2006. Green Separation Processes: Fundamentals and Applications. John Wiley \& Sons, Weinheim, Germany. 
Afschar, A.S., Vaz Rossell, C.E., Jonas, R., Quesada Chanto, A., Schaller, K., 1993. Microbial production and downstream processing of 2,3-butanediol. J. Biotechnol. 27, 317-329. doi:10.1016/01681656(93)90094-4

Agnew, D.E., Stevermer, A.K., Youngquist, J.T., Pfleger, B.F., 2012. Engineering Escherichia coli for production of C12-C14 polyhydroxyalkanoate from glucose. Metab. Eng. 14, 705-713. doi:10.1016/j.ymben.2012.08.003

Aikawa, S., Nishida, A., Ho, S.-H., Chang, J.-S., Hasunuma, T., Kondo, A., 2014. Glycogen production for biofuels by the euryhaline cyanobacteria Synechococcus sp. strain PCC 7002 from an oceanic environment. Biotechnol. Biofuels 7, 88. doi:10.1186/1754-6834-7-88

Alonso, D.M., Wettstein, S.G., Dumesic, J.A., 2012. Bimetallic catalysts for upgrading of biomass to fuels and chemicals. Chem. Soc. Rev. 41, 8075. doi:10.1039/c2cs35188a

Ambler, C.M., 1961. The fundamentals of separation, including Sharples "Sigma value" for predicting equipment performance. Ind. Eng. Chem. Res. 53, 430-433.

Andrews, B.A., Asenjo, J.A., 1987. Enzymatic lysis and disruption of microbial cells. Trends Biotechnol. 5, 273-277. doi:10.1016/0167-7799(87)90058-8

Angermayr, S.A., Gorchs Rovira, A., Hellingwerf, K.J., 2015. Metabolic engineering of cyanobacteria for the synthesis of commodity products. Trends Biotechnol. 33, 352-361. doi:10.1016/j.tibtech.2015.03.009

Antoni, D., Zverlov, V.V., Schwarz, W.H., 2007. Biofuels from microbes. Appl. Microbiol. Biotechnol. 77, 2335. doi:10.1007/s00253-007-1163-x

Anvari, M., Pahlavanzadeh, H., Vasheghani-Farahani, E., Khayati, G., 2009. In situ recovery of 2,3-butanediol from fermentation by liquid-liquid extraction. J. Ind. Microbiol. Biotechnol. 36, 313-317. doi:10.1007/s10295-008-0501-z

Asenjo, J.A., 1990. Separation Processes in Biotechnology, New York. ed. Marcel Dekker Inc.

Asenjo, J.A., Andrews, B.A., 2012. Aqueous two-phase systems for protein separation: Phase separation and applications. J. Chromatogr. A 1238, 1-10. doi:10.1016/j.chroma.2012.03.049

Asenjo, J.A., Andrews, B.A., 2008. Challenges and trends in bioseparations. J. Chem. Technol. Biotechnol. 83, 117-120. doi:10.1002/jctb.1851

Atkinson, B., Mavituna, F., 1991. Biochemical engineering and biotechnology handbook, Second. ed. Stockton Press, New York, USA. 
Babu, V., Choudhury, B., 2013. Methods of cell lysis and effect of detergents for the recovery of nitrile metabolizing enzyme from Amycolatopsis sp. IITR215. J. Genet. Eng. Biotechnol. 11, 117-122. doi:10.1016/j.jgeb.2013.05.002

Backhaus, K., Lochmüller, M., Arndt, M.C., Riechert, O., Schembecker, G., 2015. Knowledge-based conceptual synthesis of industrial-scale downstream processes for biochemical products. Chem. Eng. Technol. 38, 537-546. doi:10.1002/ceat.201400111

Bahadori, A., Clark, M., Boyd, B., 2013. Essentials of Water Systems Design in the Oil, Gas, and Chemical Processing Industries. Springer Science \& Business Media, New York, USA.

Balasundaram, B., Harrison, S., Bracewell, D.G., 2009. Advances in product release strategies and impact on bioprocess design. Trends Biotechnol. 27, 477-485. doi:10.1016/j.tibtech.2009.04.004

Balasundaram, B., Sachdeva, S., Bracewell, D.G., 2011. Dual salt precipitation for the recovery of a recombinant protein from Escherichia coli. Biotechnol. Prog. 27, 1306-1314. doi:10.1002/btpr.645

Banholzer, W.F., Jones, M.E., 2013. Chemical engineers must focus on practical solutions. AIChE J. 59, 27082720. doi:10.1002/aic.14172

Barnicki, S.D., Siirola, J.J., 2004. Process synthesis prospective. Comput. Chem. Eng. 28, 441-446. doi:10.1016/j.compchemeng.2003.09.030

Bautista, J., Chico, E., Machado, A., 1986. Cell removal from fermentation broth by flocculation + sedimentation. Biotechnol. Lett. 8, 315-318. doi:10.1007/BF01040856

Belter, P.A., Cussler, E.L., Hu, W.-S., 1988. Bioseparations: downstream processing for biotechnology. Wiley, USA.

Benavides, J., Rito-Palomares, M., Asenjo, J.A., 2011. Aqueous Two-Phase Systems, in: Moo-Young, M. (Ed.), Comprehensive Biotechnology (Second Edition). Academic Press, Burlington, pp. 697-713.

Bhayani, B.V., Ramarao, B.V., 2013. Filtration-Based Separations in the Biorefinery, in: Ramaswamy, S., Huang, H.-J., Ramarao, B.V. (Eds.), Separation and Purification Technologies in Biorefineries. John Wiley \& Sons, Ltd, pp. 327-349.

Birajdar, S.D., Padmanabhan, S., Rajagopalan, S., 2014. Rapid Solvent Screening Using Thermodynamic Models for Recovery of 2,3-Butanediol from Fermentation by Liquid-Liquid Extraction. J. Chem. Eng. Data 59, 2456-2463. doi:10.1021/je500196e

Bosma, R., Spronsen, W.A. van, Tramper, J., Wijffels, R.H., 2003. Ultrasound, a new separation technique to harvest microalgae. J. Appl. Phycol. 15, 143-153. doi:10.1023/A:1023807011027 
Bothast, R.J., Schlicher, M. a., 2005. Biotechnological processes for conversion of corn into ethanol. Appl. Microbiol. Biotechnol. 67, 19-25. doi:10.1007/s00253-004-1819-8

Brandt, K., Schembecker, G., 2016. Production rate-dependent key performance indicators for a systematic design of biochemical downstream processes. Chem. Eng. Technol. 39, 354-364. doi:10.1002/ceat.201500428

Brennan, L., Owende, P., 2010. Biofuels from microalgae-A review of technologies for production, processing, and extractions of biofuels and co-products. Renew. Sustain. Energy Rev. 14, 557-577. doi:10.1016/j.rser.2009.10.009

Brooks, Berbesi, R., Hodgson, A.S., 2015. AOCS Lipid Library [WWW Document]. http://lipidlibrary.aocs.org. URL (accessed 4.28.16).

Canilha, L., Chandel, A.K., Milessi, T.S.S., Antunes, F.A.F., Freitas, W.L.C., Felipe, M.G.A., da Silva, S.S., 2012. Bioconversion of sugarcane biomass into ethanol: An overview about composition, pretreatment methods, detoxification of hydrolysates, enzymatic saccharification, and ethanol fermentation. BioMed Res. Int. 2012, e989572. doi:10.1155/2012/989572

Carlson, E.C., 1996. Don’t gamble with physical properties for simulations. Chem. Eng. Prog.

Castanha, R.F., Morais, L.A.S. de, Mariano, A.P., Monteiro, R.T.R., 2013. Comparison of two lipid extraction methods produced by yeast in cheese whey. Braz. Arch. Biol. Technol. 56, 629-636. doi:10.1590/S1516-89132013000400013

Chai, L., Romero, D., Kayatekin, C., Akabayov, B., Vlamakis, H., Losick, R., Kolter, R., 2013. Isolation, characterization, and aggregation of a structured bacterial matrix precursor. J. Biol. Chem. 288, 17559-17568. doi:10.1074/jbc.M113.453605

Chang, D.-S., Yeh, L.-T., Liu, W., 2014. Incorporating the carbon footprint to measure industry context and energy consumption effect on environmental performance of business operations. Clean Technol. Environ. Policy 17, 359-371. doi:10.1007/s10098-014-0785-9

Cherubini, F., Strømman, A.H., 2011. Chemicals from lignocellulosic biomass: opportunities, perspectives, and potential of biorefinery systems. Biofuels Bioprod. Biorefining 5, 548-561. doi:10.1002/bbb.297

Chew, J.J., Doshi, V., 2011. Recent advances in biomass pretreatment - Torrefaction fundamentals and technology. Renew. Sustain. Energy Rev. 15, 4212-4222. doi:10.1016/j.rser.2011.09.017

Chheda, J.N., Huber, G.W., Dumesic, J.A., 2007. Liquid-Phase Catalytic Processing of Biomass-Derived Oxygenated Hydrocarbons to Fuels and Chemicals. Angew. Chem. Int. Ed. 46, 7164-7183. doi:10.1002/anie.200604274 
Chisti, Y., 1998. Strategies in Downstream Processing, in: Subramanian, G. (Ed.), Bioseparation and Bioprocessing. Wiley-VCH Verlag GmbH, pp. 1-30.

Chisti, Y., Moo-Young, M., 1996. Disruption of microbial cells for intracellular products. Enzyme Microb. Technol. 8, 194-204.

Choi, J., Lee, S.Y., 1999. Factors affecting the economics of polyhydroxyalkanoate production by bacterial fermentation. Appl. Microbiol. Biotechnol. 51, 13-21. doi:10.1007/s002530051357

Choi, J., Lee, S.Y., 1997. Process analysis and economic evaluation for Poly(3-hydroxybutyrate) production by fermentation. Bioprocess Eng. 17, 335-342. doi:10.1007/s004490050394

Clark, R., Cameron, J., Root, T., Pfleger, B., 2014. Insights into the industrial growth of cyanobacteria from a model of the carbon-concentrating mechanism. AIChE J. 60, 1269-1277. doi:10.1002/aic

Coakley, W.T., Whitworth, G., Grundy, M.A., Gould, R.K., Allman, R., 1994. Ultrasonic manipulation of particles and cells. Ultrasonic separation of cells. Bioseparation 4, 73-83.

Constantinou, L., Gani, R., 1994. New group contribution method for estimating properties of pure compounds. AIChE J. 40, 1697-1710. doi:10.1002/aic.690401011

Conti, J., Holtberg, P., Diefenderfer, J., LaRose, A., Turnure, J.T., Westfall, L., 2016. International Energy Outlook 2016 with projections to 2040 - U. S. Energy Information Administration (No. DOE/EIA0484(2016)).

Daugulis, A.J., 2001. Two-phase partitioning bioreactors: a new technology platform for destroying xenobiotics. Trends Biotechnol. 19, 457-462. doi:10.1016/S0167-7799(01)01789-9

Davidson, B.H., Lievense, J.C., 2016. Commercializing industrial biotechnology: Technology challenges and opportunities. Chem. Eng. Prog. 35-42.

Davis, R., Aden, A., Pienkos, P.T., 2011. Techno-economic analysis of autotrophic microalgae for fuel production. Appl. Energy, Special Issue of Energy from algae: Current status and future trends 88, 3524-3531. doi:10.1016/j.apenergy.2011.04.018

Diwekar, U.M., 2011. Batch Distillation: Simulation, Optimal Design, and Control, Second Edition. Taylor and Francis, CRC Press, Boca Raton, FL, USA.

Doran, P.M., 2012. Bioprocess Engineering Principles, Second. ed. Academic Press, United Kingdom.

Doshi, R., Diwekar, U., Benavides, P.T., Yenkie, K.M., Cabezas, H., 2014. Maximizing sustainability of ecosystem model through socio-economic policies derived from multivariable optimal control theory. Clean Technol. Environ. Policy 17, 1573-1583. doi:10.1007/s10098-014-0889-2 
Draaisma, R.B., Wijffels, R.H., Slegers, P.M.E., Brentner, L.B., Roy, A., Barbosa, M.J., 2013. Food commodities from microalgae. Curr. Opin. Biotechnol. 24, 169-177. doi:10.1016/j.copbio.2012.09.012

Dutta, A., Sahir, A., Tan, E., Humbrid, D., Snowden-Swan, L.J., Meyer, P., Ross, J., Sexton, D., Yap, R., Lukas, J., 2015. Process Design and Economics for the Conversion of Lignocellulosic Biomass to Hydrocarbon Fuels (Technical No. NREL/TP-5100-62455; PNNL-23823). NREL, PNNL.

Dyson, N.A., 1998. Chromatographic Integration Methods. Royal Society of Chemistry.

Elmaleh, S., Jabbouri, A., 1991. Flocculation energy requirement. Water Res. 25, 939-943. doi:10.1016/0043-1354(91)90141-C

Epp, K.A., Fetterolf, D.M., 2009. Recovery Processes. J. Valid. Technol.

Feng, X., Huang, R.Y.M., 1997. Liquid Separation by Membrane Pervaporation: A Review. Ind. Eng. Chem. Res. 36, 1048-1066. doi:10.1021/ie960189g

Filho, A.P., Medeiros Hirata, G.A., Watanabe, É.O., Miranda, É.A., 2011. Precipitation and Crystallization, in: Moo-Young, M. (Ed.), Comprehensive Biotechnology. Academic Press, Burlington, pp. 651-663.

Flörke, M., Kynast, E., Bärlund, I., Eisner, S., Wimmer, F., Alcamo, J., 2013. Domestic and industrial water uses of the past 60 years as a mirror of socio-economic development: A global simulation study. Glob. Environ. Change 23, 144-156. doi:10.1016/j.gloenvcha.2012.10.018

Freese, H.L., 1996. 10 - Evaporation, in: Todaro, H.C.V.L. (Ed.), Fermentation and Biochemical Engineering Handbook (Second Edition). William Andrew Publishing, Westwood, NJ, pp. 476-534.

Gani, R., Nielsen, B., Fredenslund, A., 1991. A group contribution approach to computer-aided molecular design. AIChE J. 37, 1318-1332. doi:10.1002/aic.690370905

Garcia, F.A.P., Pires, E.M.V., 1993. Chromatography, in: Kennedy, J.F., Cabral, J.M.S. (Eds.), Recovery Processes for Biological Materials. pp. 415-452.

Ghosh, R., 2006. Principles of Bioseparations Engineering. World Scientific, Singapore.

Glasgow, S.M., 2014. Chapter 15 - Crystallization, in: Todaro, H.C.V.M. (Ed.), Fermentation and Biochemical Engineering Handbook (Third Edition). William Andrew Publishing, Boston, pp. 309-318.

Gnansounou, E., Dauriat, A., 2010. Techno-economic analysis of lignocellulosic ethanol: A review. Bioresour. Technol., Special Issue on Lignocellulosic Bioethanol: Current Status and Perspectives 101, 49804991. doi:10.1016/j.biortech.2010.02.009

Gorak, A., Sorensen, E., 2014. Distillation: Fundamentals and Principles. Academic Press.

Grandison, A.S., Lewis, M.J., 1996. Separation Processes in the Food and Biotechnology Industries. CRC Press. 
Günerken, E., D’Hondt, E., Eppink, M.H.M., Garcia-Gonzalez, L., Elst, K., Wijffels, R.H., 2015. Cell disruption for microalgae biorefineries. Biotechnol. Adv. 33, 243-260. doi:10.1016/j.biotechadv.2015.01.008

Hahn-Hagerdal, B., Wahlbom, C.F., Gardonyi, M., van Zyl, W.H., Cordero Otero, R.R., Jonsson, L.J., 2001. Metabolic Engineering of Saccharomyces cerevisiae for xylose utilization. Adv. Biochem. Eng. Biotechnol. 73.

Hamelinck, C.N., Hooijdonk, G. van, Faaij, A.P., 2005. Ethanol from lignocellulosic biomass: techno-economic performance in short-, middle- and long-term. Biomass Bioenergy 28, 384-410. doi:10.1016/j.biombioe.2004.09.002

Han, J., Murat Sen, S., Luterbacher, J.S., Alonso, D.M., Dumesic, J.A., Maravelias, C.T., 2015. Process systems engineering studies for the synthesis of catalytic biomass-to-fuels strategies. Comput. Chem. Eng., Special Issue: Selected papers from the 8th International Symposium on the Foundations of Computer-Aided Process Design (FOCAPD 2014), July 13-17, 2014, Cle Elum, Washington, USA 81, 57-69. doi:10.1016/j.compchemeng.2015.04.007

Hanotu, J., Bandulasena, H.C.H., Zimmerman, W.B., 2012. Microflotation performance for algal separation. Biotechnol. Bioeng. 109, 1663-1673. doi:10.1002/bit.24449

Harker, J.H., Backhurst, J.R., Richardson, J.F., 2002. Coulson and Richardson's Chemical Engineering Volume 2, Fifth edition. ed. Butterworth-Heinemann, Oxford, UK.

Harrison, R.G., Todd, P., Rudge, S.R., Petrides, D.P., 2003. Bioseparations Science and Engineering. Oxford University Press.

Harrison, S.T.L., 1991. Bacterial cell disruption: A key unit operation in the recovery of intracellular products. Biotechnol. Adv. 9, 217-240. doi:10.1016/0734-9750(91)90005-G

Hatti-Kaul, R., 2001. Aqueous two-phase systems. Mol. Biotechnol. 19, 269-277. doi:10.1385/MB:19:3:269

Hatti-Kaul, R., Mattiasson, B., 2003. Isolation and Purification of Proteins. Marcel Dekker Inc., New York, USA.

Hill, P., 2005. Batch crystallization, in: Korovessi, E., Linninger, A.A. (Eds.), Batch Processes. Taylor and Francis, CRC Press, New York, USA.

Hirokawa, Y., Maki, Y., Tatsuke, T., Hanai, T., 2016. Cyanobacterial production of 1,3-propanediol directly from carbon dioxide using a synthetic metabolic pathway. Metab. Eng. 34, 97-103. doi:10.1016/j.ymben.2015.12.008

Ho, S.-H., Huang, S.-W., Chen, C.-Y., Hasunuma, T., Kondo, A., Chang, J.-S., 2013. Bioethanol production using carbohydrate-rich microalgae biomass as feedstock. Bioresour. Technol., Biorefineries 135, 191198. doi:10.1016/j.biortech.2012.10.015 
Ho, W., Sirkar, K., 1992. Membrane Handbook. Springer, New York, USA.

Huang, R.Y.M., 1991. Pervaporation Membrane Separation Processes, 1 edition. ed. Elsevier Science, Amsterdam ; New York.

Huber, G.W., Chheda, J.N., Barrett, C.J., Dumesic, J.A., 2005. Production of Liquid Alkanes by Aqueous-Phase Processing of Biomass-Derived Carbohydrates. Science 308, 1446-1450. doi:10.1126/science.1111166

Huber, G.W., Iborra, S., Corma, A., 2006. Synthesis of transportation fuels from biomass: chemistry, catalysts, and engineering. Chem. Rev. 106, 4044-4098. doi:10.1021/cr068360d

Hulatt, C.J., Thomas, D.N., 2011. Productivity, carbon dioxide uptake and net energy return of microalgal bubble column photobioreactors. Bioresour. Technol. 102, 5775-5787. doi:10.1016/j.biortech.2011.02.025

Humbird, D., Davis, R., Tao, L., Kinchin, C., Hsu, D., Aden, A., Schoen, P., Lukas, J., Olthof, B., Worley, M., Sexton, D., Dudgeon, D., 2011. Process Design and Economics for Biochemical Conversion of Lignocellulosic Biomass to Ethanol: Dilute-Acid Pretreatment and Enzymatic Hydrolysis of Corn Stover (No. NREL/TP-5100-47764). National Renewable Energy Laboratory (NREL), Golden, CO.

Janssen, A.C.J.M., Kierkels, J.G.T., Lentzen, G.F., 2015. Two-phase fermentation process for the production of an organic compound. W02015002528 A1.

Jeon, S., Kim, D.-K., Song, H., Lee, H.J., Park, S., Seung, D., Chang, Y.K., 2014. 2,3-Butanediol recovery from fermentation broth by alcohol precipitation and vacuum distillation. J. Biosci. Bioeng. 117, 464-470. doi:10.1016/j.jbiosc.2013.09.007

Joback, K.G., Reid, R.C., 1987. Estimation of Pure-Component Properties from Group-Contributions. Chem. Eng. Commun. 57, 233-243. doi:10.1080/00986448708960487

Jones, C.M., Hernandez Lozada, N.J., Pfleger, B.F., 2015. Efflux systems in bacteria and their metabolic engineering applications. Appl. Microbiol. Biotechnol. 99, 9381-9393. doi:10.1007/s00253-0156963-9

Jones, M.E., Banholzer, W.F., 2014. Solar flux, water, and land impose limits on biology. Biotechnol. Bioeng. 111, 1059-61. doi:10.1002/bit.25228

Jönsson, A.-S., 2013. Microfiltration, Ultrafiltration and Diafiltration, in: Ramaswamy, S., Huang, H.-J., Ramarao, B.V. (Eds.), Separation and Purification Technologies in Biorefineries. John Wiley \& Sons, Ltd, pp. 205-231. 
Jorquera, O., Kiperstok, A., Sales, E.A., Embiruçu, M., Ghirardi, M.L., 2010. Comparative energy life-cycle analyses of microalgal biomass production in open ponds and photobioreactors. Bioresour. Technol. 101, 1406-1413. doi:10.1016/j.biortech.2009.09.038

Jullesson, D., David, F., Pfleger, B., Nielsen, J., 2015. Impact of synthetic biology and metabolic engineering on industrial production of fine chemicals. Biotechnol. Adv. doi:10.1016/j.biotechadv.2015.02.011

Kathiresan, S., Sarada, R., Bhattacharya, S., Ravishankar, G.A., 2007. Culture media optimization for growth and phycoerythrin production from Porphyridium purpureum. Biotechnol. Bioeng. 96, 456-463. doi:10.1002/bit.21138

Kennedy, J.F., Cabral, J.M.S. (Eds.), 1993. Recovery Processes for Biological Materials, 1 edition. ed. Wiley, Chichester England; New York.

Kim, J., Sen, S.M., Maravelias, C.T., 2013. An optimization-based assessment framework for biomass-to-fuel conversion strategies. Energy Environ. Sci. 6, 1093. doi:10.1039/c3ee24243a

Kiss, A.A., Grievink, J., Rito-Palomares, M., 2015. A systems engineering perspective on process integration in industrial biotechnology. J. Chem. Technol. Biotechnol. 90, 349-355. doi:10.1002/jctb.4584

Knoop, H., Steuer, R., 2015. A computational analysis of stoichiometric constraints and trade-offs in cyanobacterial biofuel production. Front. Bioeng. Biotechnol. doi:10.3389/fbioe.2015.00047

Koch, J., Shiveler, G., 2015. Design Principles for Liquid-Liquid Extraction. Chem. Eng. Prog.

Kokossis, A.C., Tsakalova, M., Pyrgakis, K., 2015. Design of integrated biorefineries. Comput. Chem. Eng., Special Issue: Selected papers from the 8th International Symposium on the Foundations of Computer-Aided Process Design (FOCAPD 2014), July 13-17, 2014, Cle Elum, Washington, USA 81, 40-56. doi:10.1016/j.compchemeng.2015.05.021

Koros, W.J., Ma, Y.H., Shimidzu, T., 1996. Pure and Applied Chemistry. Pure \& Appl. Chem. 68, 1479-1489.

Kuenz, A., Gallenmüller, Y., Willke, T., Vorlop, K.-D., 2012. Microbial production of itaconic acid: developing a stable platform for high product concentrations. Appl. Microbiol. Biotechnol. 96, 1209-1216. doi:10.1007/s00253-012-4221-y

Kurian, J.V., 2005. A New Polymer Platform for the Future - Sorona®. J. Polym. Environ. 13, 159-167. doi:10.1007/s10924-005-2947-7

Lea-Smith, D.J., Bombelli, P., Vasudevan, R., Howe, C.J., 2015. Photosynthetic, respiratory and extracellular electron transport pathways in cyanobacteria. Biochim. Biophys. Acta. doi:10.1016/j.bbabio.2015.10.007 
Lee, A.K., Lewis, D.M., Ashman, P.J., 2013. Harvesting of marine microalgae by electroflocculation: The energetics, plant design, and economics. Appl. Energy 108, 45-53. doi:10.1016/j.apenergy.2013.03.003

Lee, A.K., Lewis, D.M., Ashman, P.J., 2010. Energy requirements and economic analysis of a full-scale microbial flocculation system for microalgal harvesting. Chem. Eng. Res. Des. 88, 988-996. doi:10.1016/j.cherd.2010.01.036

Lee, E., Pruvost, J., He, X., Munipalli, R., Pilon, L., 2014. Design tool and guidelines for outdoor photobioreactors. Chem. Eng. Sci. 106, 18-29. doi:10.1016/j.ces.2013.11.014

Leeper, S.A., Andrews, G.F., 1991. A critical review and evaluation of bioproduction of organic chemicals. Appl. Biochem. Biotechnol. 28-29, 499-511. doi:10.1007/BF02922629

Lei, Z., Chen, B., 2013. Distillation, in: Ramaswamy, S., Huang, H.-J., Ramarao, B.V. (Eds.), Separation and Purification Technologies in Biorefineries. John Wiley \& Sons, Ltd, pp. 37-60.

Lewis, M.J., 1996. Chapter 4 - Ultrafiltration, in: Grandison, A.S., Lewis, M.J. (Eds.), Separation Processes in the Food and Biotechnology Industries, Woodhead Publishing Series in Food Science, Technology and Nutrition. Woodhead Publishing, pp. 97-139.

Liao, J.C., Mi, L., Pontrelli, S., Luo, S., 2016. Fuelling the future: microbial engineering for the production of sustainable biofuels. Nat. Rev. Microbiol. doi:10.1038/nrmicro.2016.32

Lienqueo, M.E., Asenjo, J.A., 2000. Use of expert systems for the synthesis of downstream protein processes. Comput. Chem. Eng. 24, 2339-2350. doi:10.1016/S0098-1354(00)00590-1

Lipinsky, E.S., 1981. Chemicals from biomass: petrochemical substitution options. Science 212, 1465-1471. doi:10.1126/science.212.4502.1465

Li, Q., Du, W., Liu, D., 2008. Perspectives of microbial oils for biodiesel production. Appl. Microbiol. Biotechnol. 80, 749-756. doi:10.1007/s00253-008-1625-9

List, G.R., 2009. Bleaching and Purifying Fats and Oils: Theory and Practice. Elsevier.

Liu, L., Liu, Y., Li, J., Du, G., Chen, J., 2011. Microbial production of hyaluronic acid: current state, challenges, and perspectives. Microb. Cell Factories 10, 99. doi:10.1186/1475-2859-10-99

Luna, C.L., Lopes, C.E., Massarani, G., 2005. Recovery of Bacillus sphaericus spores by flocculation/sedimentation and flotation. Braz. Arch. Biol. Technol. 48, 61-70. doi:10.1590/S151689132005000400008 
Lymperiadis, A., Adjiman, C.S., Jackson, G., Galindo, A., 2008. A generalisation of the SAFT- group contribution method for groups comprising multiple spherical segments. Fluid Phase Equilibria, Special Section: 4th Fluid Properties Challenge 274, 85-104. doi:10.1016/j.fluid.2008.08.005

Lynd, L.R., Weimer, P.J., van Zyl, W.H., Pretorius, I.S., 2002. Microbial Cellulose Utilization: Fundamentals and Biotechnology. Microbiol. Mol. Biol. Rev. 66, 506-577. doi:10.1128/MMBR.66.3.506

Machmudah, S., Shotipruk, A., Goto, M., Sasaki, M., Hirose, T., 2006. Extraction of Astaxanthin from Haematococcus p luvialis Using Supercritical $\mathrm{CO}_{2}$ and Ethanol as Entrainer. Ind. Eng. Chem. Res. 45, 3652-3657. doi:10.1021/ie051357k

Mänttäri, M., Van der Bruggen, B., Nyström, M., 2013. Nanofiltration, in: Ramaswamy, S., Huang, H.-J., Ramarao, B.V. (Eds.), Separation and Purification Technologies in Biorefineries. John Wiley \& Sons, Ltd, pp. 233-258.

Marquardt, W., Harwardt, A., Hechinger, M., Kraemer, K., Viell, J., Voll, A., 2010. The biorenewables opportunity - toward next generation process and product systems. AIChE J. 56, 2228-2235. doi:10.1002/aic.12380

Martin, V.J.J., Pitera, D.J., Withers, S.T., Newman, J.D., Keasling, J.D., 2003. Engineering a mevalonate pathway in Escherichia coli for production of terpenoids. Nat. Biotechnol. 21, 796-802. doi:10.1038/nbt833

Mavrovouniotis, M.L., 1990. Group contributions for estimating standard gibbs energies of formation of biochemical compounds in aqueous solution. Biotechnol. Bioeng. 36, 1070-1082. doi:10.1002/bit.260361013

Melendres, A.V., Unno, H., 1992. A concept of critical velocity for cell disruption by bead mill. J. Chem. Eng. Jpn. - J CHEM ENG JPN 25, 354-356. doi:10.1252/jcej.25.354

Miranda, J.R., Passarinho, P.C., Gouveia, L., 2012. Pre-treatment optimization of Scenedesmus obliquus microalga for bioethanol production. Bioresour. Technol. 104, 342-348. doi:10.1016/j.biortech.2011.10.059

Molina Grima, E., Belarbi, E.-H., Acién Fernández, F.G., Robles Medina, A., Chisti, Y., 2003. Recovery of microalgal biomass and metabolites: process options and economics. Biotechnol. Adv. 20, 491-515. doi:10.1016/S0734-9750(02)00050-2

Mondal, M.K., Balsora, H.K., Varshney, P., 2012. Progress and trends in CO2 capture/separation technologies: A review. Energy, Energy and Exergy Modelling of Advance Energy Systems 46, 431441. doi:10.1016/j.energy.2012.08.006

Mooibroek, H., Oosterhuis, N., Giuseppin, M., Toonen, M., Franssen, H., Scott, E., Sanders, J., Steinbüchel, A., 2007. Assessment of technological options and economical feasibility for cyanophycin biopolymer 
and high-value amino acid production. Appl. Microbiol. Biotechnol. 77, 257-267. doi:10.1007/s00253-007-1178-3

Morrissey, K.L., Keirn, M.I., Inaba, Y., Denham, A.J., Henry, G.J., Vogler, B.W., Posewitz, M.C., Stoykovich, M.P., 2015. Recyclable polyampholyte flocculants for the cost-effective dewatering of microalgae and cyanobacteria. Algal Res. 11, 304-312. doi:10.1016/j.algal.2015.07.009

Moss, R.H., Edmonds, J.A., Hibbard, K.A., Manning, M.R., Rose, S.K., van Vuuren, D.P., Carter, T.R., Emori, S., Kainuma, M., Kram, T., Meehl, G.A., Mitchell, J.F.B., Nakicenovic, N., Riahi, K., Smith, S.J., Stouffer, R.J., Thomson, A.M., Weyant, J.P., Wilbanks, T.J., 2010. The next generation of scenarios for climate change research and assessment. Nature 463, 747-756. doi:10.1038/nature08823

Mulder, M.H.V., Hendrikman, J.O., Hegeman, H., Smolders, C.A., 1983. Ethanol-water separation by pervaporation. J. Membr. Sci. 16, 269-284.

Najafpour, G., 2015. Biochemical Engineering and Biotechnology, Second. ed. Elsevier, Waltham, MA, USA.

Nelson, D.L., Cox, M.M., 2008. Lehninger Principles of Biochemistry, 5th edition. ed. W. H. Freeman, New York.

Nfor, B.K., Ahamed, T., van Dedem, G.W., van der Wielen, L.A., van de Sandt, E.J., Eppink, M.H., Ottens, M., 2008. Design strategies for integrated protein purification processes: challenges, progress and outlook. J. Chem. Technol. Biotechnol. 83, 124-132. doi:10.1002/jctb.1815

OECD, 2009. The Bioeconomy to 2030. Organisation for Economic Co-operation and Development, Paris.

Özdural, A.R., 2011. 2.48 - Modeling Chromatographic Separation A2 - Moo-Young, Murray, in: Comprehensive Biotechnology (Second Edition). Academic Press, Burlington, pp. 681-695.

Pacheco, C.R.F., Stella, S.S., 1998. CALCULATING CAPACITY TRENDS IN ROTARY DRYERS. Braz. J. Chem. Eng. 15, 235-245. doi:10.1590/S0104-66321998000300002

Palsson, B.O., Fathi-Afshar, S., Rudd, D.F., Lightfoot, E.N., 1981. Biomass as a source of chemical feedstocks: an economic evaluation. Science 213, 513-517. doi:10.1126/science.213.4507.513

Papaioannou, V., Adjiman, C.S., Jackson, G., Galindo, A., 2011. Group Contribution Methodologies for the Prediction of Thermodynamic Properties and Phase Behavior in Mixtures, in: Pistikopoulos, E.N., Georgiadis, M.C., Dua, V., Adjiman, C.S., Galindo, A. (Eds.), Process Systems Engineering. Wiley-VCH Verlag GmbH \& Co. KGaA, pp. 135-172.

Pavia, D.L., 2005. Introduction to Organic Laboratory Techniques: A Small Scale Approach. Cengage Learning. 
Peters, G.P., Andrew, R.M., Boden, T., Canadell, J.G., Ciais, P., Le Quéré, C., Marland, G., Raupach, M.R., Wilson, C., 2013. The challenge to keep global warming below $2{ }^{\circ} \mathrm{C}$. Nat. Clim. Change 3, 4-6. doi:10.1038/nclimate1783

Petrides, D.P., 2013. Intelligen, Inc.: SuperPro Designer, Batch Process Simulation, Environmental Impact Assessment. Intelligen Inc.

Pham, T.N., Shi, D., Resasco, D.E., 2014. Evaluating strategies for catalytic upgrading of pyrolysis oil in liquid phase. Appl. Catal. B Environ., Advances in Catalysis for Biomass Valorization 145, 10-23. doi:10.1016/j.apcatb.2013.01.002

Philp, J., 2015. Balancing the bioeconomy: supporting biofuels and bio-based materials in public policy. Energy Environ. Sci. doi:10.1039/C5EE01864A

Pisano, R., Fissore, D., Barresi, A.A., Rastelli, M., 2013. Quality by Design: Scale-Up of Freeze-Drying Cycles in Pharmaceutical Industry. AAPS PharmSciTech 14, 1137-1149. doi:10.1208/s12249-013-0003-9

Postma, P.R., Miron, T.L., Olivieri, G., Barbosa, M.J., Wijffels, R.H., Eppink, M.H.M., 2015. Mild disintegration of the green microalgae Chlorella vulgaris using bead milling. Bioresour. Technol., Advances in biofuels and chemicals from algae 184, 297-304. doi:10.1016/j.biortech.2014.09.033

Prins, M.J., Ptasinski, K.J., Janssen, F.J.J.G., 2006. More efficient biomass gasification via torrefaction. Energy, ECOS 2004 - 17th International Conference on Efficiency, Costs, Optimization, Simulation, and Environmental Impact of Energy on Process Systems17th International Conference on Efficiency, Costs, Optimization, Simulation, and Environmental Impact of Energy on Process Systems 31, 34583470. doi:10.1016/j.energy.2006.03.008

Pulz, O., Gross, W., 2004. Valuable products from biotechnology of microalgae. Appl. Microbiol. Biotechnol. 65, 635-648. doi:10.1007/s00253-004-1647-x

Quintana, N., Van der Kooy, F., Van de Rhee, M.D., Voshol, G.P., Verpoorte, R., 2011. Renewable energy from Cyanobacteria: energy production optimization by metabolic pathway engineering. Appl. Microbiol. Biotechnol. 91, 471-490. doi:10.1007/s00253-011-3394-0

Qureshi, N., Hughes, S., Maddox, I.S., Cotta, M.A., 2005. Energy-efficient recovery of butanol from model solutions and fermentation broth by adsorption. Bioprocess Biosyst. Eng. 27, 215-222. doi:10.1007/s00449-005-0402-8

Ramli, M.R., Siew, W.L., Ibrahim, N.A., Hussein, R., Kuntom, A., Abd. Razak, R.A., Nesaretnam, K., 2011. Effects of degumming and bleaching on 3-MCPD esters formation during physical refining. J. Am. Oil Chem. Soc. 88, 1839-1844. doi:10.1007/s11746-011-1858-0

Rao, D.G., 2010. Introduction to Biochemical Engineering. Tata McGraw-Hill Education. 
Riesenberg, D., Guthke, R., 1999. High-cell-density cultivation of microorganisms. Appl. Microbiol. Biotechnol. 51, 422-430. doi:10.1007/s002530051412

Rizwan, M., Lee, J.H., Gani, R., 2013. Optimal processing pathway for the production of biodiesel from microalgal biomass: A superstructure based approach. Comput. Chem. Eng. 58, 305-314. doi:10.1016/j.compchemeng.2013.08.002

Rosgaard, L., de Porcellinis, A.J., Jacobsen, J.H., Frigaard, N.-U., Sakuragi, Y., 2012. Bioengineering of carbon fixation, biofuels, and biochemicals in cyanobacteria and plants. J. Biotechnol. 162, 134-47. doi:10.1016/j.jbiotec.2012.05.006

Rossini, M., Garrido, J.G., Galluzzo, M., 1999. Optimization of the coagulation-flocculation treatment: influence of rapid mix parameters. Water Res. 33, 1817-1826. doi:10.1016/S0043-1354(98)003674

Ruiz-Ruiz, F., Benavides, J., Rito-Palomares, M., 2013. Scaling-up of a B-phycoerythrin production and purification bioprocess involving aqueous two-phase systems: Practical experiences. Process Biochem. 48, 738-745. doi:10.1016/j.procbio.2013.02.010

Ryu, H.W., Cho, K.S., Chang, Y.K., Chang, H.N., 1996. Cell separation from high cell density broths of Alcaligenes eutrophus. Biotechnol. Tech. 10, 899-904. doi:10.1007/BF00180391

Salehizadeh, H., Shojaosadati, S.A., 2001. Extracellular biopolymeric flocculants: Recent trends and biotechnological importance. Biotechnol. Adv. 19, 371-385. doi:10.1016/S0734-9750(01)00071-4

Salte, H., King, J.M., Baganz, F., Hoare, M., Titchener-Hooker, N.J., 2006. A methodology for centrifuge selection for the separation of high solids density cell broths by visualisation of performance using windows of operation. Biotechnol. Bioeng. 95, 1218-1227.

Sanders, J., Scott, E., Weusthuis, R., Mooibroek, H., 2007. Bio-Refinery as the Bio-Inspired Process to Bulk Chemicals. Macromol. Biosci. 7, 105-117. doi:10.1002/mabi.200600223

Sarada, R., Vidhyavathi, R., Usha, D., Ravishankar, G.A., 2006. An efficient method for extraction of astaxanthin from green alga Haematococcus pluvialis. J. Agric. Food Chem. 54, 7585-7588. doi:10.1021/jf060737t

Sayyed, R.Z., Gangurde, N.S., Chincholkar, S.B., 2009. Hypochlorite digestion method for efficient recovery of PHB from Alcaligenes faecalis. Indian J. Microbiol. 49, 230-232. doi:10.1007/s12088-009-0036-7

Schewe, J., Heinke, J., Gerten, D., Haddeland, I., Arnell, N.W., Clark, D.B., Dankers, R., Eisner, S., Fekete, B.M., Colón-González, F.J., Gosling, S.N., Kim, H., Liu, X., Masaki, Y., Portmann, F.T., Satoh, Y., Stacke, T., Tang, Q., Wada, Y., Wisser, D., Albrecht, T., Frieler, K., Piontek, F., Warszawski, L., Kabat, P., 2014. 
Multimodel assessment of water scarcity under climate change. Proc. Natl. Acad. Sci. 111, 32453250. doi:10.1073/pnas.1222460110

Scopes, R.K., 1994. Protein Purification. Springer, New York, USA.

Scott, E., Peter, F., Sanders, J., 2007. Biomass in the manufacture of industrial products-the use of proteins and amino acids. Appl. Microbiol. Biotechnol. 75, 751-762. doi:10.1007/s00253-007-0932-x

Seader, J.D., Henley, E.J., Roper, D.K., 2010. Separation Process Principles with Applications using Process Simulators, 4 edition. ed. Wiley, Hoboken, NJ.

Shaeiwitz, J.A., Henry, J.D., Ghosh, R., 2000. Bioseparation, in: Ullmann's Encyclopedia of Industrial Chemistry. Wiley-VCH Verlag GmbH \& Co.

Shao, P., Kumar, A., 2009. Recovery of 2,3-butanediol from water by a solvent extraction and pervaporation separation scheme. J. Membr. Sci. 329, 160-168. doi:10.1016/j.memsci.2008.12.033

Sharma, N.K., Rai, A.K., Stal, L.J., 2013. Cyanobacteria: An Economic Perspective, 1 edition. ed. WileyBlackwell, United Kingdom.

Sheldon, T.J., Adjiman, C.S., Cordiner, J.L., 2005. Pure component properties from group contribution: Hydrogen-bond basicity, hydrogen-bond acidity, Hildebrand solubility parameter, macroscopic surface tension, dipole moment, refractive index and dielectric constant. Fluid Phase Equilibria 231, 27-37. doi:10.1016/j.fluid.2004.12.017

Shimoni, Y., Moehrle, V., Srinivasan, V., 2013. Process Improvements Increase Production Capacity of a Legacy Product. BioProcess Int.

Show, K.-Y., Lee, D.-J., Chang, J.-S., 2013. Algal biomass dehydration. Bioresour. Technol., Biorefineries 135, 720-729. doi:10.1016/j.biortech.2012.08.021

Shukla, A.A., Etzel, M.R., Gadam, S., 2006. Process Scale Bioseparations for the Biopharmaceutical Industry. CRC Press.

Shuler, M.L., Kargi, F., 1992. Bioprocess engineering: basic concepts. Prentice Hall, New Jersey, USA.

Siddiqui, S., Friedman, D., Alper, J., 2013. Opportunities and Obstacles in Large-Scale Biomass Utilization: The Role of the Chemical Sciences and Engineering Communities: A Workshop Summary. National Academies Press, Washington, D.C.

Sikdar, S.K., Burckle, J., Rogut, J., 2001. Separation methods for environmental technologies. Environ. Prog. 20,1-11. doi:10.1002/ep.670200109

Sikdar, S.K., Cole, K.D., Stewart, R.M., Szlag, D.C., Todd, P., Cabezas, H., 1991. Aqueous Two-Phase Extraction In Bioseparations: An Assessment. Nat. Biotechnol. 9, 252-256. doi:10.1038/nbt0391-252 
Sikdar, S.K., Todd, P.W., Bier, M., 1989. Frontiers in Bioprocesssing. CRC Press, Boca Raton, FL, USA.

Singh, P.C., Singh, R.K., 1996. Choosing an appropriate bioseparation technique. Trends Food Sci. Technol. 7, 49-58. doi:10.1016/0924-2244(96)81328-8

Singh, S.M., Panda, A.K., 2005. Solubilization and refolding of bacterial inclusion body proteins. J. Biosci. Bioeng. 99, 303-310. doi:10.1263/jbb.99.303

Steffens, M.A., Fraga, E.S., Bogle, I.D., 2000. Synthesis of bioprocesses using physical properties data. Biotechnol. Bioeng. 68, 218-230.

Sun, Y., Shi, Q.-H., Zhang, L., Zhao, G.-F., Liu, F.-F., 2011. Adsorption and Chromatography, in: Moo-Young, M. (Ed.), Comprehensive Biotechnology (Second Edition). Academic Press, Burlington, pp. 665-679.

Tee, T.W., Chowdhury, A., Maranas, C.D., Shanks, J.V., 2014. Systems metabolic engineering design: Fatty acid production as an emerging case study. Biotechnol. Bioeng. 111, 849-857. doi:10.1002/bit.25205

Todaro, C.M., Vogel, H.C., 2014. Fermentation and Biochemical Engineering Handbook. William Andrew, Elsevier, Waltham, MA, USA.

Towler, G., Sinnott, R.K., 2012. Chemical Engineering Design, Second Edition: Principles, Practice and Economics of Plant and Process Design, 2 edition. ed. Butterworth-Heinemann, Boston, MA.

Valentínyi, N., Cséfalvay, E., Mizsey, P., 2013. Modelling of pervaporation: Parameter estimation and model development. Chem. Eng. Res. Des. 91, 174-183. doi:10.1016/j.cherd.2012.07.001

Vandamme, D., Foubert, I., Muylaert, K., 2013. Flocculation as a low-cost method for harvesting microalgae for bulk biomass production. Trends Biotechnol. 31, 233-239. doi:10.1016/j.tibtech.2012.12.005

Van der Stelt, M.J.C., Gerhauser, H., Kiel, J.H.A., Ptasinski, K.J., 2011. Biomass upgrading by torrefaction for the production of biofuels: A review. Biomass Bioenergy 35, 3748-3762. doi:10.1016/j.biombioe.2011.06.023

Van Hee, P., Hoeben, M. a., van der Lans, R. g. j. m., van der Wielen, L. a. m., 2006. Strategy for selection of methods for separation of bioparticles from particle mixtures. Biotechnol. Bioeng. 94, 689-709. doi:10.1002/bit.20885

Van Reis, R., Zydney, A., 2007. Bioprocess membrane technology. J. Membr. Sci. 297, 16-50. doi:10.1016/j.memsci.2007.02.045

Van Reis, R., Zydney, A., 2001. Membrane separations in biotechnology. Curr. Opin. Biotechnol. 12, $208-211$. doi:10.1016/S0958-1669(00)00201-9 
Varzakas, T., Tzia, C., 2015. Handbook of Food Processing: Food Safety, Quality, and Manufacturing Processes. Taylor and Francis, CRC Press, Boca Raton, FL, USA.

Venkatesan, S., 2013. Adsorption, in: Ramaswamy, S., Huang, H.-J., Ramarao, B.V. (Eds.), Separation and Purification Technologies in Biorefineries. John Wiley \& Sons, Ltd, pp. 101-148.

Vennestrøm, P.N.R., Osmundsen, C.M., Christensen, C.H., Taarning, E., 2011. Beyond Petrochemicals: The Renewable Chemicals Industry. Angew. Chem. Int. Ed. 50, 10502-10509. doi:10.1002/anie.201102117

Verrall, M., 1996. Wiley: Downstream Processing of Natural Products: A Practical Handbook. John Wiley \& Sons, Inc., United Kingdom.

Vranch, S.P., Collins, C.H., Beale, A.J., 1992. Engineering for safe bioprocessing, in: Safety in Industrial Microbiology and Biotechnology. Butterworth-Heinemann, United Kingdom, pp. 176-189.

Walter, H., Johansson, G., 1994. Aqueous Two-phase Systems. Elsevier.

Wang, C., Li, Q., Tang, H., Zhou, W., Yan, D., Xing, J., Wan, Y., 2013. Clarification of succinic acid fermentation broth by ultrafiltration in succinic acid bio-refinery. J. Chem. Technol. Biotechnol. 88, 444-448. doi:10.1002/jctb.3834

Wang, W., Singh, M., 2013. Biological Drug Products: Development and Strategies. John Wiley \& Sons, Inc., New Jersey, USA.

Wang, Z., Zhuge, J., Fang, H., Prior, B.A., 2001. Glycerol production by microbial fermentation: A review. Biotechnol. Adv. 19, 201-223. doi:10.1016/S0734-9750(01)00060-X

Willke, T., Vorlop, K.-D., 2001. Biotechnological production of itaconic acid. Appl. Microbiol. Biotechnol. 56, 289-295. doi:10.1007/s002530100685

Worley, M., Yale, J., Dutta, A., 2012. Biomass Gasification Technology Assessment (Technical No. NREL/SR5100-57085).

Wu, W., Henao, C.A., Maravelias, C.T., 2016. A superstructure representation, generation, and modeling framework for chemical process synthesis. AIChE J.

Yang, H., Xu, Z., Fan, M., Gupta, R., Slimane, R.B., Bland, A.E., Wright, I., 2008. Progress in carbon dioxide separation and capture: A review. J. Environ. Sci. 20, 14-27. doi:10.1016/S1001-0742(08)60002-9

Yao, L., Qi, F., Tan, X., Lu, X., 2014. Improved production of fatty alcohols in cyanobacteria by metabolic engineering. Biotechnol. Biofuels 7, 94. doi:10.1186/1754-6834-7-94

Yeomans, H., Grossmann, I.E., 1999. A systematic modeling framework of superstructure optimization in process synthesis. Comput. Chem. Eng. 23, 709-731. doi:10.1016/S0098-1354(99)00003-4 
Yoon, S.-H., 2015. Membrane Bioreactor Processes: Principles and Applications. Taylor and Francis, CRC Press, Boca Raton, FL, USA.

Youngquist, J.T., Schumacher, M.H., Rose, J.P., Raines, T.C., Politz, M.C., Copeland, M.F., Pfleger, B.F., 2013. Production of medium chain length fatty alcohols from glucose in Escherichia coli. Metab. Eng. 20, 177-186. doi:10.1016/j.ymben.2013.10.006

Zeng, A.-P., Biebl, H., 2002. Bulk Chemicals from Biotechnology: The Case of 1,3-Propanediol Production and the New Trends, in: Scheper, T. (Ed.), Tools and Applications of Biochemical Engineering Science, Advances in Biochemical Engineering/Biotechnology. Springer Berlin Heidelberg, pp. 239259.

Zhang, H., Cheng, Y.-T., Vispute, T.P., Xiao, R., Huber, G.W., 2011. Catalytic conversion of biomass-derived feedstocks into olefins and aromatics with ZSM-5: the hydrogen to carbon effective ratio. Energy Environ. Sci. 4, 2297-2307. doi:10.1039/C1EE01230D 


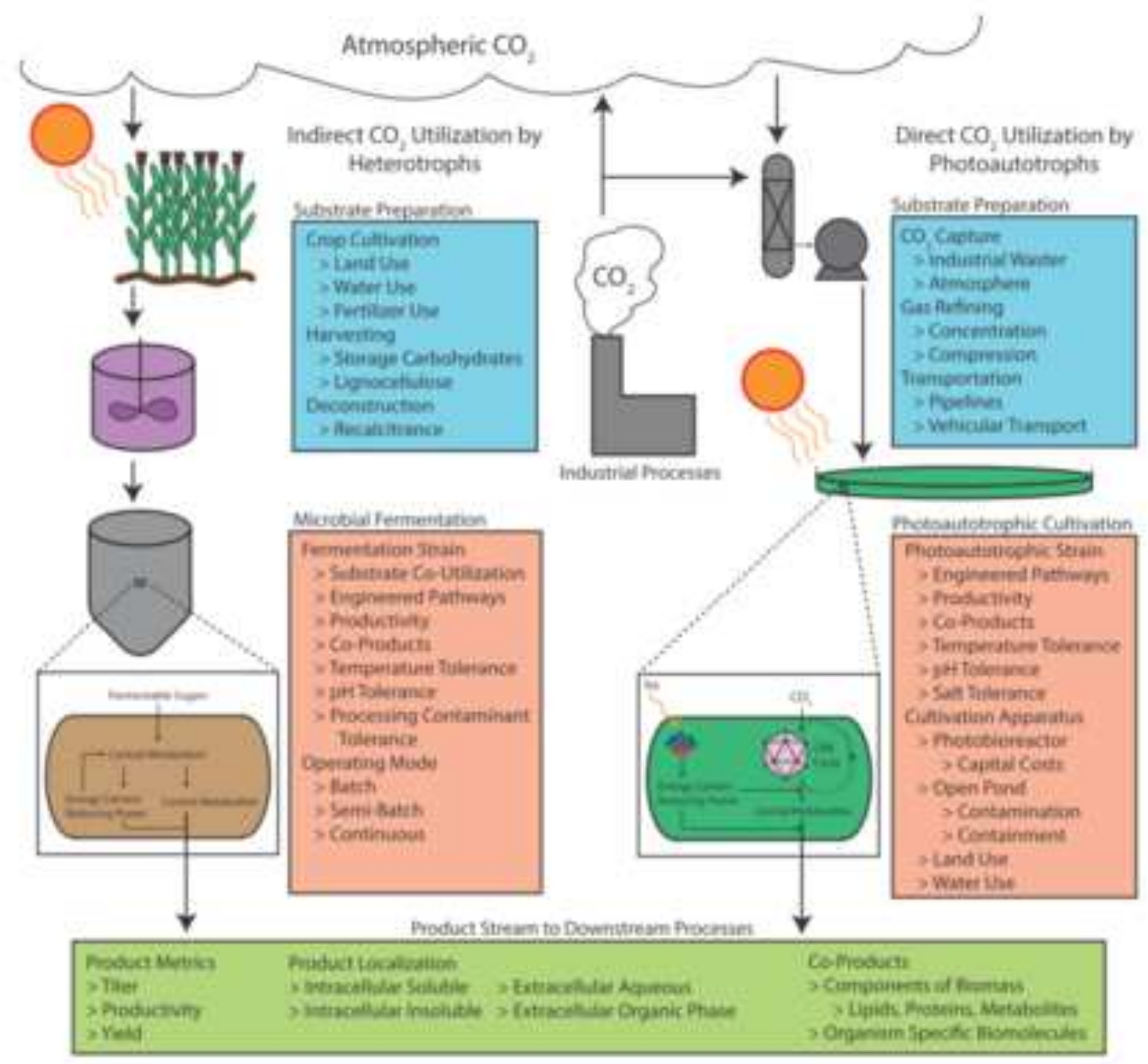




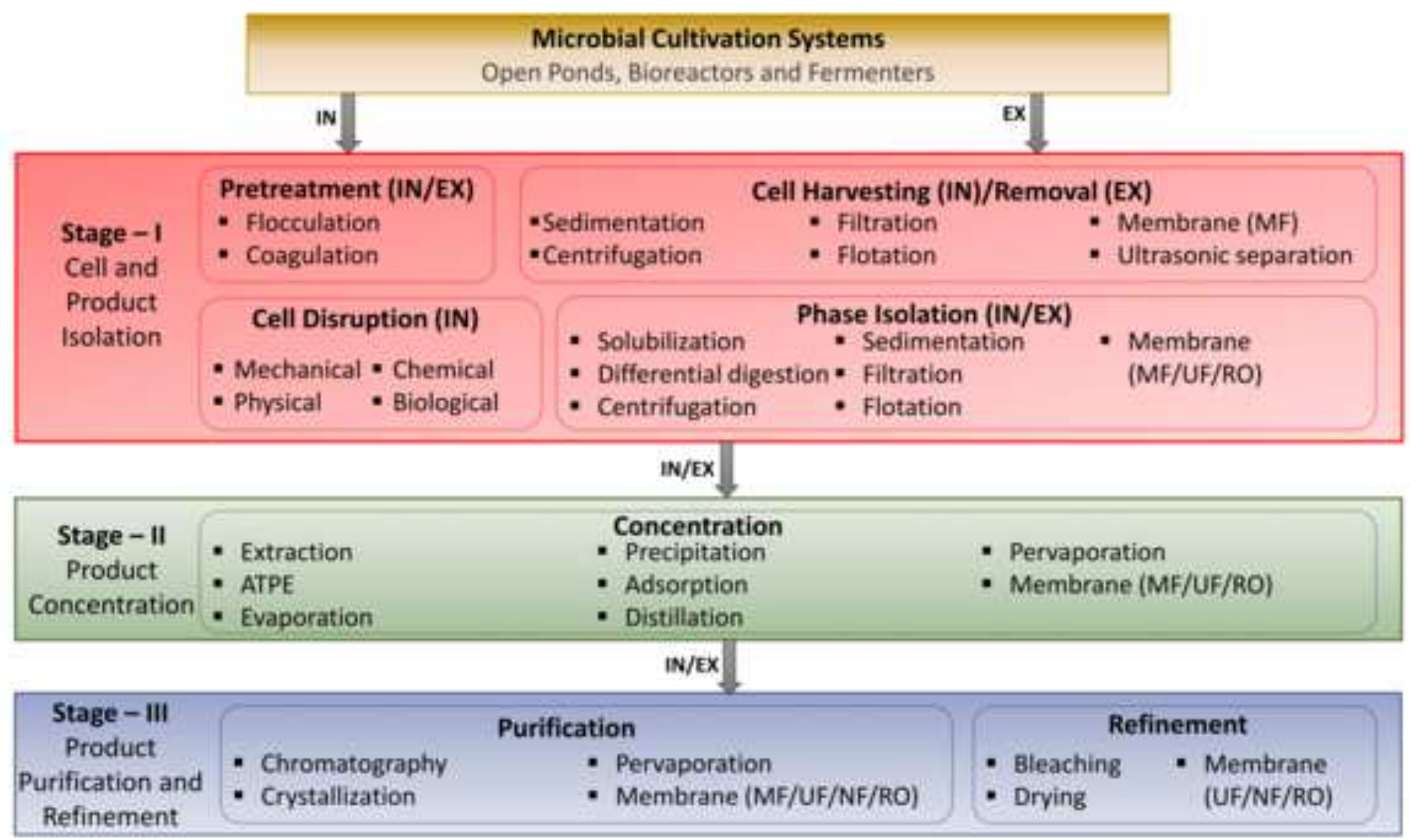


Stage 1
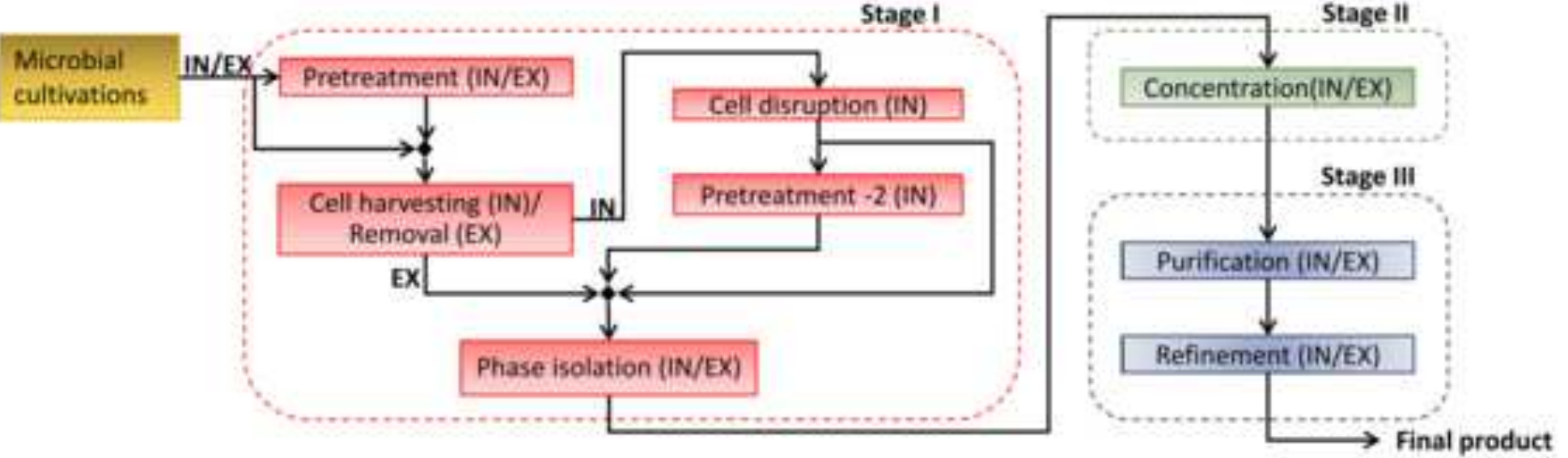


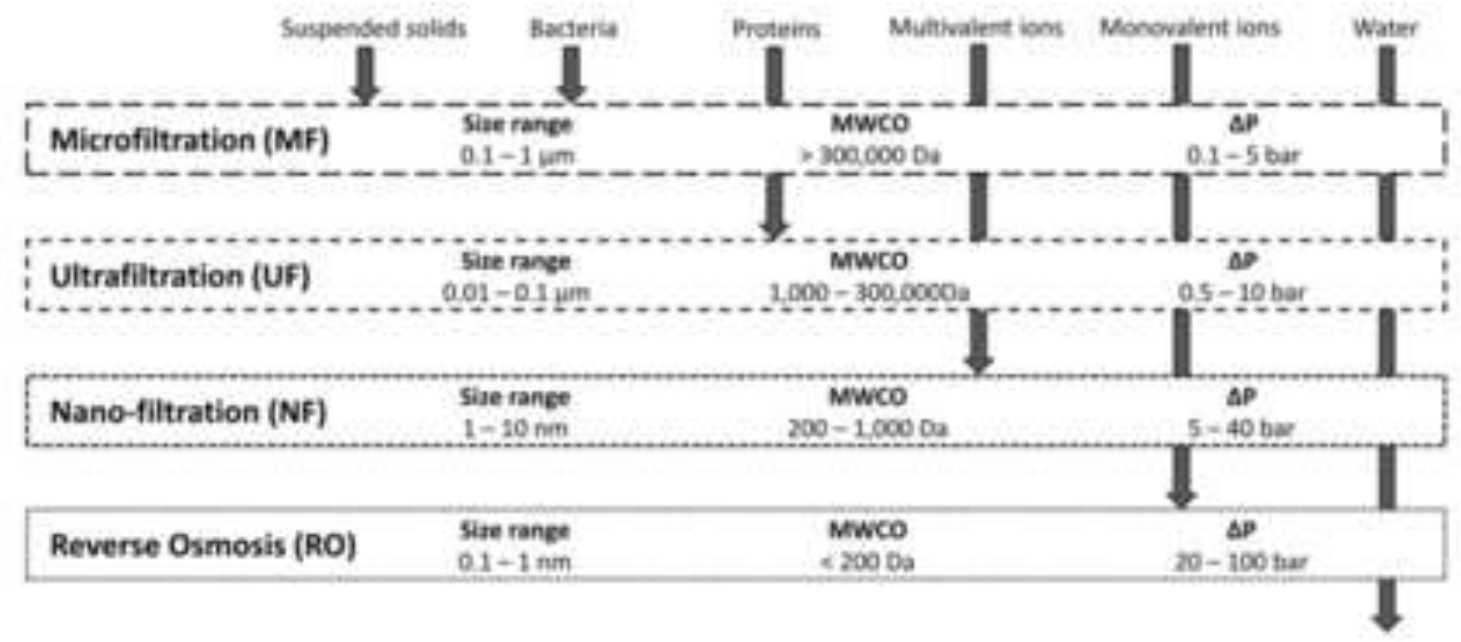




\begin{tabular}{|c|c|c|c|c|c|c|}
\hline $\begin{array}{l}\text { Upstream } \\
\text { processing }\end{array}$ & & Cell and $\mathrm{p}$ & rage 1 - & & $\begin{array}{l}\text { Stagen ill product } \\
\text { concentration }\end{array}$ & $\begin{array}{l}\text { Stage } 111 \text {-Product } \\
\text { purification } 8 \text { refinement }\end{array}$ \\
\hline $\begin{array}{l}\text { - Microbial } \\
\text { cultivations } \\
\text { - Process stream } \\
\text { characterization }\end{array}$ & $\begin{array}{l}\text { Pretreatment } \\
\text {-flocculation". } \\
\text {-Coagulation"* }\end{array}$ & 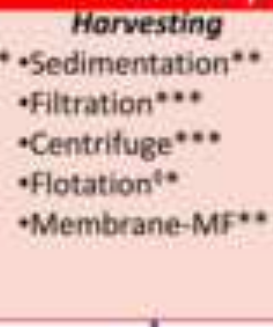 & $\begin{array}{l}\text { Disruption } \\
\text { - Eead mill *.. } \\
\text {-HPH* } \\
\text {-Enzyme } \\
\text { lysis"*.. } \\
\text {-Chemical } \\
\text { lysis }\end{array}$ & $\begin{array}{l}\text { Phase isolation } \\
\text {-Sedimentation* } \\
\text {-Filtration"... } \\
\text {-Centrifuge"... } \\
\text {-Flotation". } \\
\text {-Membrane-all*... } \\
\text {-Solubilization "... } \\
\text {-Differential digestion ... }\end{array}$ & $\begin{array}{l}\text { Centrifuge }{ }^{* . .} \\
\text { - Membrane-all... } \\
\text { - Precipitation(Sjo... } \\
\text { - Adsorption }\end{array}$ & $\begin{array}{l}\text { - Bleaching }{ }^{* *} \\
\text {-Chromatography(L) } \\
\text { - Drying }(S)^{* * *}\end{array}$ \\
\hline$\uparrow$ & Vater recycle. & & & & \multicolumn{2}{|c|}{$\begin{array}{l}\text { "Fair } \quad * \text { Good } \quad * \text { Excellent: } \\
\text { 'Some conditions apply } \\
\text { Physical state of product: (S) - solid \& (L) - Liquid }\end{array}$} \\
\hline
\end{tabular}




\begin{tabular}{|c|c|c|c|c|c|c|}
\hline $\begin{array}{l}\text { Upstream } \\
\text { processing }\end{array}$ & \multicolumn{4}{|c|}{$\begin{array}{l}\text { Stage f- } \\
\text { Cell and product isolation }\end{array}$} & \multirow{2}{*}{ 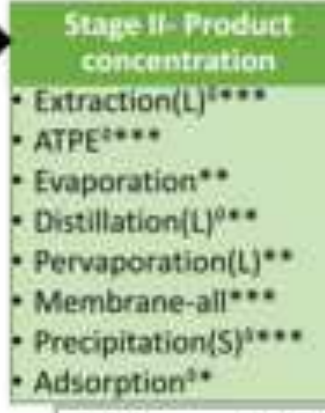 } & $\begin{array}{l}\text { Stage ill-Product } \\
\text { purification } 8 \text { refinement }\end{array}$ \\
\hline $\begin{array}{l}\text { - Microbial } \\
\text { cultivations } \\
\text { - Process stream } \\
\text { characterization }\end{array}$ & $\begin{array}{l}\text { Pretreotment } \\
\text { - Flocculation**. } \\
\text {-Coagulation }\end{array}$ & $\begin{array}{l}\text { Harvesting } \\
\text {-Sedimentation*. } \\
\text {-Filtration*... } \\
\text {-Centrifuge*..* } \\
\text {-Flotation"* } \\
\text {-Membrane-MF** }\end{array}$ & $\begin{array}{l}\text { Disruption } \\
\text {-Bead mill**. } \\
\text {-HPH** } \\
\text { +Enryme } \\
\text { Iysis"*.. } \\
\text { *Chemical } \\
\text { Iysis"** }\end{array}$ & 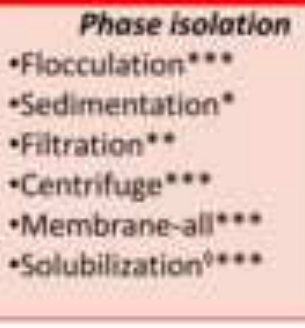 & & 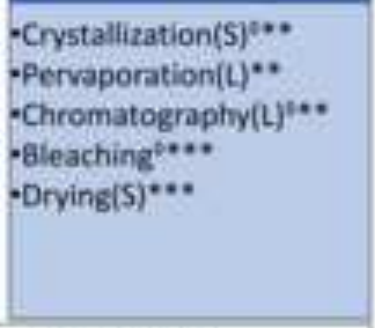 \\
\hline \multicolumn{5}{|c|}{ Water recycle } & \multicolumn{2}{|c|}{$\begin{array}{l}\text { "Fair } \quad * \text { Good } \quad \cdots \text { Excellent } \\
\text { "Some conditions apply } \\
\text { Physical state of product: (S) - solid \& (L) - Liquid }\end{array}$} \\
\hline
\end{tabular}




\begin{tabular}{|c|c|c|c|c|}
\hline $\begin{array}{l}\text { Upstream } \\
\text { processing }\end{array}$ & \multicolumn{2}{|c|}{$\begin{array}{c}\text { Stage :- } \\
\text { Cell and product isolation }\end{array}$} & $\begin{array}{l}\text { Stage lit prodoct } \\
\text { concentration }\end{array}$ & $\begin{array}{l}\text { Stage III-Product } \\
\text { purification \& refinement }\end{array}$ \\
\hline $\begin{array}{l}\text { - Microbial } \\
\text { cultivations } \\
\text { - Process stream } \\
\text { characterization }\end{array}$ & $\begin{array}{l}\text { Pretreatment } \\
\text { - Flocculation*.." } \\
\text {-Coagulation }\end{array}$ & $\begin{array}{l}\text { Cell removal and phase isolotion } \\
\text { - Sedimentation* } \\
\text { - Filtration"... } \\
\text { - Centrifuge... } \\
\text { - Flotation } \\
\text { - Membrane-MF/all... } \\
\text { - Solubilization".. }\end{array}$ & $\begin{array}{l}\text { - Centrifuge** } \\
\text { - Membrane-all**. } \\
\text { - Precipitation(S) } \\
\text { - Adsorption }\end{array}$ & $\begin{array}{l}\text {-Chromatography(L)".. } \\
\text { - Bleaching }{ }^{1 . .} \\
\text { - Drying (S) } \cdots\end{array}$ \\
\hline$\uparrow$ & ter recycle & & $\begin{array}{l}\text { "Fair } \quad * \text { Go } \\
\text { "Some conditions } \\
\text { Physical state of pr }\end{array}$ & $\begin{array}{l}\text { "*Excellent } \\
(\$) \text { - solid \& (L) - Liquid }\end{array}$ \\
\hline
\end{tabular}




\begin{tabular}{|c|c|c|c|c|}
\hline $\begin{array}{l}\text { Upstream } \\
\text { processing }\end{array}$ & \multicolumn{2}{|c|}{$\begin{array}{l}\text { Stage } 1- \\
\text { Cell and product isolation }\end{array}$} & \multirow{2}{*}{ 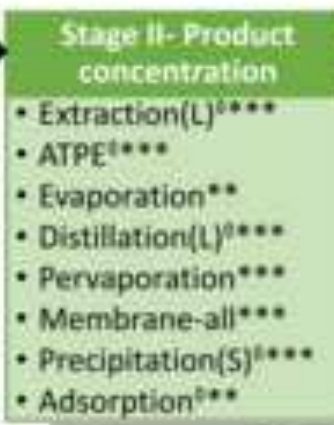 } & \multirow{2}{*}{ 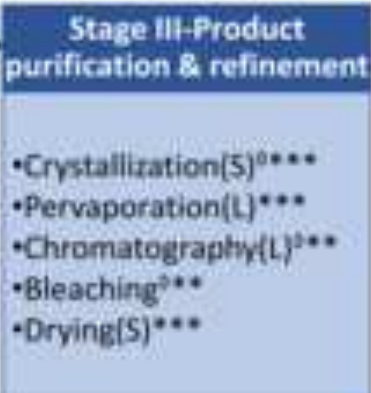 } \\
\hline $\begin{array}{l}\text { - Microbial } \\
\text { cultivations } \\
\text { - Process stream } \\
\text { characterization }\end{array}$ & $\begin{array}{l}\text { Pretreatment } \\
\text {-Flocculation"*. } \\
\text {-Coagulation }\end{array}$ & $\begin{array}{l}\text { Cell removal and phase isolation } \\
\text { - Sedimentation* } \\
\text { - Filtration*... } \\
\text { - Centrifuge... } \\
\text { - Flotation } \\
\text { - Membrane-MF/all*.. } \\
\text { - Solubilization }\end{array}$ & & \\
\hline$\uparrow$ & er recycle & & \multicolumn{2}{|c|}{$\begin{array}{l}\text { "Fair } \quad * \text { Good } \quad * * \text { Excellent } \\
\text { "Some conditions apply } \\
\text { Physical state of product: }(S) \text { - solid \& (L) - Liquid }\end{array}$} \\
\hline
\end{tabular}




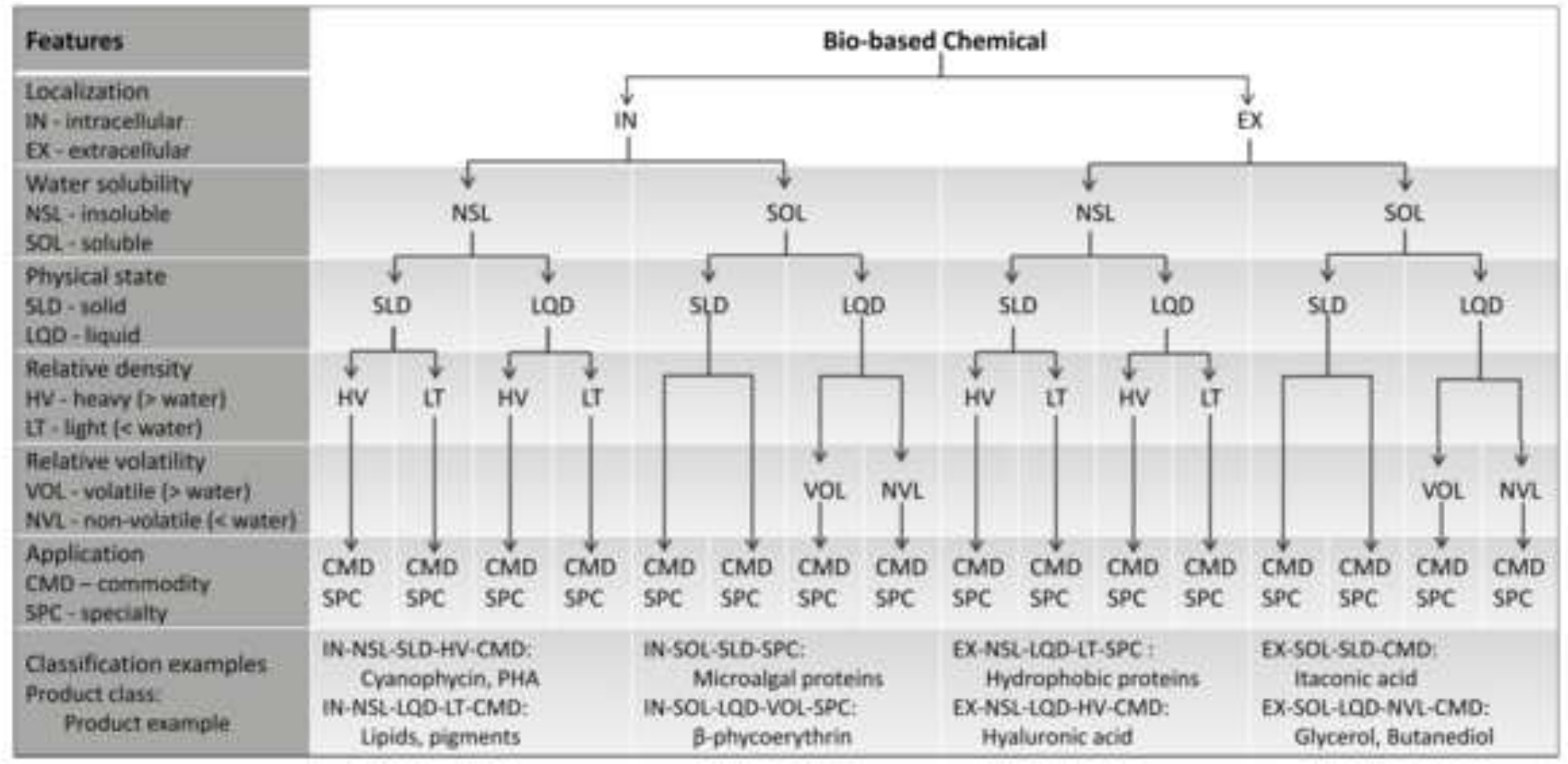




\begin{tabular}{|c|c|c|c|c|}
\hline $\begin{array}{l}\text { Upitrnam } \\
\text { procering }\end{array}$ & \multicolumn{2}{|c|}{$\begin{array}{l}\text { Stabel- } \\
\text { Cell and praduct isolation }\end{array}$} & $\begin{array}{l}\text { 3euse } 11-\text { Product } \\
\text { cancentustiog: }\end{array}$ & $\begin{array}{l}\text { Staige hil-Product } \\
\text { purificrtion \& refinement }\end{array}$ \\
\hline $\begin{array}{l}\text { - Microbial } \\
\text { cultivatioes } \\
\text { - Procets stream } \\
\text { characterization }\end{array}$ & 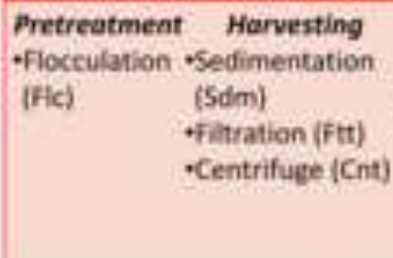 & 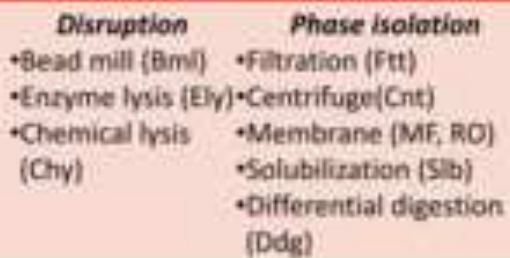 & $\begin{array}{l}\text { Membrane (MF) } \\
\text { - Precipitation (Prc) }\end{array}$ & -DryingtDryl \\
\hline \multicolumn{3}{|c|}{ Water recycle } & \multicolumn{2}{|c|}{$\begin{array}{l}\text { "Fair "Good } \quad \text { "*Excellent } \\
\text { "Some conditions apply } \\
\text { Phrsical state of product: (5) - solid \& (L) - Liquid }\end{array}$} \\
\hline
\end{tabular}




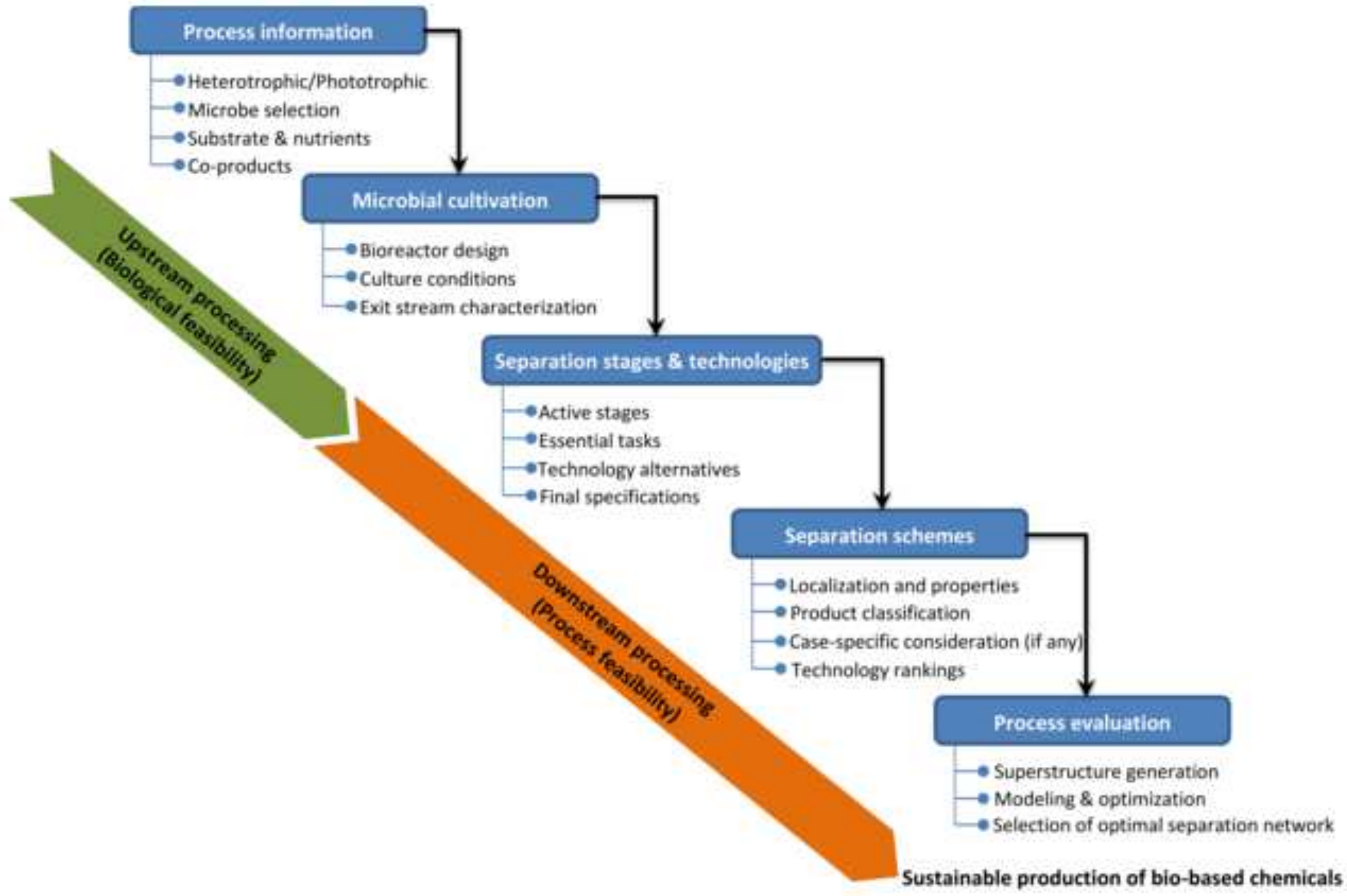

